\title{
A MARKET FOR HUMAN ORGANS: AN ETHICAL SOLUTION TO THE ORGAN SHORTAGE
}

\author{
Adam Crepelle*
}

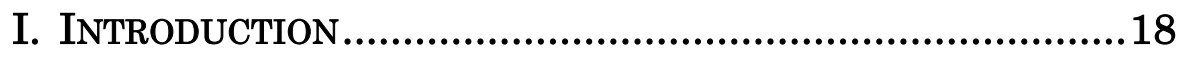

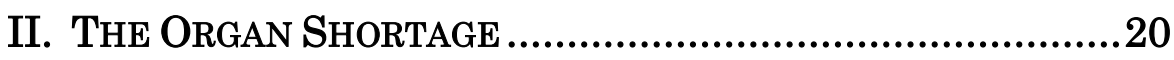

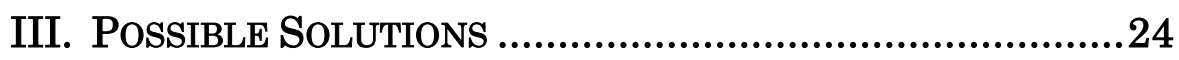

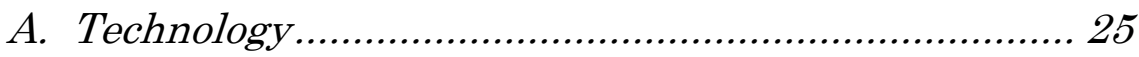

B. Presumed Consent .............................................. 28

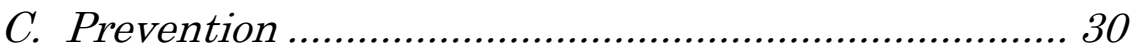

D. Facilitate Living Donation...................................... 32

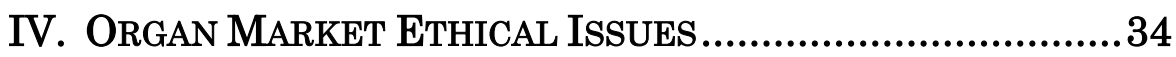

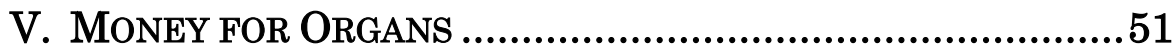

A. Black Market............................................................ 52

B. Iranian Kidney System ........................................ 57

VI. ANALYSIS AND CRITIQUe OF IRAN'S KIDNEY SYSTEM ......63

VII. AN ORGAN MARKET IN THE UNITED STATES..................69

A. Live Organ Market.............................................. 69

B. Cadaver Organ Market ......................................... 76

VIII. CONSEQUENCES OF ORGAN MARKET.............................77

IX. CONCLUSION ..................................................................

* Master of Public Policy, Pepperdine University School of Public Policy 2015. Juris Doctorate, Southern University Law Center, 2013. Bachelor of Science in Exercise Science, University of Louisiana at Lafayette, 2009. I would like to extend my sincerest thanks to Dr. Robert Kaufman of Pepperdine University School of Public Policy and Dr. Sigrid Fry-Revere of the Center for Ethical Solutions. Dr. Kaufman advised me throughout the writing process. His objective commentary on a thesis that he does not agree with is an example all intellectuals should aspire to. Dr. Fry-Revere's courageous research helped inspire my interest in bioethics. She was also kind enough to comment on my paper. 


\begin{abstract}
Over 120,000 people are waiting for an organ transplant. Twenty-one Americans die each day waiting for an organ. This problem is not unique to the United States. Although technological advancements will likely end the organ shortage one day, technological solutions to the shortage are likely decades away. An organ market is the only solution currently available to the organ shortage.

The human organ market is almost universally condemned for ethical reasons. However, the ethical objections to a market do not withstand scrutiny. Only one nation allows individuals to sell their kidneys, and this is the only nation to eliminate its kidney waiting list. Moreover, the poor and middle classes have greater access to kidneys in this nation than any other country. This nation is Iran.

The United States should recognize the success of Iran's kidney system and implement an organ market. Creating an organ market in the United States only requires a few changes to the current organ procurement system. Most importantly, a market will improve health outcomes for those in need of organs and likely reduce healthcare costs as well.
\end{abstract}

\title{
I. INTRODUCTION
}

In the United States, over 30,000 organ transplants were performed in 2015. ${ }^{1}$ Although this is a remarkable number of lives saved, the waiting list for organ transplants is over 120,000 candidates long, ${ }^{2}$ and the list keeps growing. A name

1 Organ Procurement and Transplantation Network, U.S. DEP'T. HEALTH \& HUMAN SERV., https://optn.transplant.hrsa.gov/news/morethan-30-000-transplants-performed-annually-for-first-time-in-unitedstates/ [https://perma.cc/WHA4-3CMN] (last visited Jan. 29, 2016].

2 UNITED NETWORK FOR ORGAN SHARING, http://www.unos.org/ [http://perma.cc/375F-LJN3] (last visited Nov. 5, 2015). 
is added every twelve minutes. ${ }^{3}$ Consequently, a shortage of organs exists. This shortage results in the death of twentyone Americans each day, ${ }^{4}$ and this figure does not include the number of people who die without being placed in the organ queue. 5 Since 1980, more Americans have died waiting for an organ than in all of the nation's wars combined. ${ }^{6}$ The dearth of organs is not just an American problem. The world average is four transplantable organs available for every 100 people in need. ${ }^{7}$

In an attempt to procure an organ, some individuals seek directed donations from living donors. Many turn to family and friends. If this option fails, people have solicited strangers to part with their organs using newspaper advertisements, billboards, and websites like jimneedsakidney.com. ${ }^{8}$ Directed donation enables the wouldbe organ recipient to bypass the organ waitlist. However, many are unable to procure an organ through this method. This causes an unknown number of people to turn to the black market in a desperate attempt to save their lives.

One nation has solved its kidney shortage. Since the dawn of the twenty-first century, the country has not had a

3 Facts and Myths, AM. TRANSPlant Found., http:// www.americantransplantfoundation.org/ab-transplant/facts-and-myths/ [http://perma.cc/J8TE-QC76] (last visited Nov. 30, 2015].

4 Id.

5 Peter Aziz, Establishing a Free Market in Human Organs: Economic Reasoning and the Perfectly Competitive Model, 31 UNIV. LA VERNE L. REV. 67, 77 (2009) ("This number does not take into account all the people who have died without being placed on the waiting list.").

6 Sigrid Fry-Revere \& David Donadio, America's Organ Transplant Law Is Criminally Unfair to Donors, New Republic (Oct. 23, 2014), http://www.newrepublic.com/article/119963/us-organ-transplant-lawneeds-reform-let-donors-get-reimbursed [http://perma.cc/6Y3Y-QXGM].

7 Sigrid Fry-Revere, What Can Iran Teach Us About the Kidney Shortage?, (TEDMED broadcast 2015), available at http://tedmed.com/ talks/show?id=309108 [http://perma.cc/EZ7Z-8YCU].

8 Eric Horng \& Andrew Fies, Ads, Billboard Plead for Organ Donations, ABC NEWs (July 24, 2005), http://abcnews.go.com/WNT/ Health/story?id=982806 [http://perma.cc/LMH4-E3FX]. 
waiting list for kidneys. ${ }^{9}$ Technology plays little role in the country's ability to provide organs. In fact, the nation has a small healthcare budget and lacks medical equipment. ${ }^{10}$ The country is poor and often regarded as backwards. Nevertheless, by compensating kidney providers, the country has solved a problem that continues to plague the world. The country is Iran.

This paper will provide an overview of the organ shortage and consider various solutions to it. Arguments for and against the market for human organs will be examined. An analysis of organ procurement on the black market and in Iran follows, as they are the only systems currently in operation where organs are exchanged for money. A market for organs in the United States is proposed and the market's probable consequences are considered. A conclusion follows.

\section{The ORGAN ShORTAGE}

The organ shortage is a result of medical advancements. The first organ transplant was performed in 1954, and potent anti-rejection drugs were approved in 1983, which greatly expanded the opportunity for successful transplants. ${ }^{11}$ Congress passed the National Organ Transplant Act in 1984 ("NOTA") creating a task force to examine "the medical, legal, ethical, economic, and social issues presented by human organ procurement and transplantation." ${ }^{2}$ This task force

9 Ahad J. Ghods \& Shekoufeh Savaj, Iranian Model of Paid and Regulated Living-Unrelated Kidney Donation, 1 CLINICAL J. AM S. NEPHROLOGY 1136, 1137 (2006) (stating Iran's renal transplant waiting list was eliminated in 1999).

10 See Ahad J. Ghods, Renal Transplantation in Iran, 17 NEPHROLOGY Dialysis TRANSPlantation 222, 226 (2002) (discussing why renal transplant survival rates may be lower than survival rates in other countries).

11 Organ Transplant History, LIVE ON NY, http:// www.donatelifeny.org/all-about-transplantation/organ-transplanthistory/ [http://perma.cc/9VND-YJDY] (last visited Nov. 30, 2015].

12 National Organ Transplant Act [NOTA], Pub. L. No. 98-507, § 101(b)(1)(A), 98 Stat. 2339 (1984). 
reflects Congress' concern that the poor would feel pressured to exchange their organs for monetary gain. ${ }^{13}$ Accordingly, Congress prohibited the interstate transfer of human organs for profit while permitting organ donations. ${ }^{14}$

Although the sale of organs is prohibited, people are allowed to donate their organs. NOTA created the Organ Procurement and Transplantation Network ("OPTN") to facilitate organ donation. ${ }^{15}$ The OPTN created a list of individuals in need of organs, criteria for donor-recipient pairing, as well as guidelines for organ acquisition and transportation. ${ }^{16}$ NOTA requires the OPTN's functions to be carried out by "a private nonprofit entity."17 The United Network for Organ Sharing ("UNOS") received the initial contract in 1986 and has been the OPTN's contractor ever since. ${ }^{18}$

In an effort to increase the supply of organs, the United States Department of Health and Human Services ("HHS") has posted materials on its website to help colleges and hospitals promote organ donation. ${ }^{19}$ Additionally, HHS promotes several national events to encourage organ donation, such as National Donor Day (February 14th) and the National Donor Recognition Ceremony \& Workshop. ${ }^{20}$

13 Gwen Mayes, Buying and Selling Organs for Transplantation in the US: National Organ Transplant Act of 1984 (NOTA) Bans Buying and Selling, MEDSCAPE, http://www.medscape.org/viewarticle/465200_2 (last visited Nov. 6, 2015).

1442 U.S.C. $\$ 274 \mathrm{e}$ (a) (2015).

1542 U.S.C. $\$ 274$ (2015), available at http://history.nih.gov/research/ downloads/PL98-507.pdf [http://perma.cc/2JJY-UVSN].

16 NOTA, Pub. L. No. 98-507, § 372(b)(2)(A)(D), 98 Stat. 2344 (1984).

1742 U.S.C. $\S 274(\mathrm{~b})(1)(\mathrm{A})(2015)$.

18 History \& NOTA, U.S. DeP'T. OF Health and Human Serv., http://optn.transplant.hrsa.gov/governance/about-the-optn/history-nota/ [http://perma.cc/E28D-F2MF] (last visited Nov. 6, 2015).

19 Campus Partner Support Materials, ORGANDONOR.GOV http:// www.organdonor.gov/materialsresources/materialscampussupport.html [http://perma.cc/8Y9N-5HU8] (last visited Nov. 6, 2015).

20 National Events, ORGONDONOR.GOV, http://www.organdonor.gov/ materialsresources/materialsntlevents.html [http://perma.cc/GC5GBEQL] (last visited Nov. 6, 2015). 
The donations sought are secured by having individuals consent to become donors at death. This occurs by agreeing to become a donor when renewing one's driver's license or through a state online registry. ${ }^{21}$ Organs from living donors are also welcomed. ${ }^{22}$

Cadavers are the source of kidneys in about two-thirds of kidney transplants; 23 however, kidneys are the most commonly transplanted organ from live donors. ${ }^{24}$ Live kidney donations are common for two reasons. One is that kidneys are the most demanded organ: over $80 \%$ of 121,588 people in need of an organ are seeking a kidney. ${ }^{25}$ The second reason for the high rate of live kidney donation relative to other organs is that most people have two kidneys, but only need one. ${ }^{26}$ This makes removing kidneys a fairly simple procedure and involves few postoperative health risks. The University of Maryland Medical Center states, "[c]urrent research indicates that kidney donation does not change life

21 Organ Donation: The Process, ORGandONOR.GOV, http:// www.organdonor.gov/about/organdonationprocess.html\#process1 [http:// perma.cc/9PTM-E9LG] (last visited Nov. 6, 2015).

22 Living Donation Information You Need to Know, UnITED NETWORK FOR ORGAN SHARING (2015), available at http://www.unos.org/ docs/Living_Donation.pdf [http://perma.cc/8ZPH-EWKC].

23 Organ Donation and Transplantation Statistics, NAT'L KIDNEY FouND., https://www.kidney.org/news/newsroom/factsheets/OrganDonation-and-Transplantation-Stats [http://perma.cc/G3BL-L5LH] (last visited Nov. 30, 2015).

24 Frequently Asked Questions About Living Donation, UNOS TRANSPLANT LIVING, http://www.transplantliving.org/living-donation/ facts/frequently-asked-questions/\#ld [http://perma.cc/96EU-JX2Z] (last visited Nov. 6, 2015).

25 Data, Organ Procurement and Transplantation Network, U.S. DEP'T. HEALTH \& HUMAN SERV., https://optn.transplant.hrsa.gov/ converge/data/ [https://perma.cc/ET4C-UADA] (last visited Jan. 29, 2016) (follow "National Data"; "select report," then "choose category", "waiting list"; "candidates"; "step 2", overall by organ").

26 Living with One Kidney, NAT'L KIDNEY FOUND., https:// www.kidney.org/atoz/content/onekidney [http://perma.cc/Q3KV-RVBK] (last visited Nov. 30, 2015). 
expectancy or increase a person's risks of developing kidney disease or other health problems." 27

Livers are the organ with the second highest demand, ${ }^{28}$ and live liver donations can also be made. ${ }^{29}$ Nevertheless, donating a liver is much more troublesome than donating a kidney. People only have one liver; thus, the donor's liver must be split by the surgeon to provide for the recipient. Accordingly, approximately one in 300 liver donors die from surgical complications and 30 percent suffer complications. ${ }^{30}$ For this reason only about four percent of the liver transplants performed in 2014 used live donors. ${ }^{31}$ Likewise, living heart, lung, and other organ donations are extremely rare, so cadavers are the primary source for these organs. ${ }^{32}$

The dearth of organs has resulted in the use of low quality organs. ${ }^{33}$ In fact, the organs of cancer patients have been

27 Frequently Asked Questions, Univ. Maryland Med. Ctr., http://umm.edu/programs/transplant/services/kidney/livingdonor/faq\#q6 [http://perma.cc/9RJL-3PNS] (last visited Nov. 6, 2015).

28 Data, supra note 25.

29 About Living Donation, AM. TRAnsplant Found., http:// www.americantransplantfoundation.org/about-transplant/livingdonation/about-living-donation/ [http://perma.cc/F47S-LCDP] (last visited Nov 6, 2015).

$30 Q$ and $A$ on Living Donor Liver Transplantation, UNIV. MARYLAND MED. CTR., http://umm.edu/programs/transplant/services/liver/livingdonor/q-and-a-on-living-donor-liver-transplantation [http://perma.cc/ WV8V-8U6B] (last visited Nov. 30, 2015).

31 Data, supra note 25. (To find current numbers, follow "National data", "select report, choose category, transplant", "choose organ, liver", "transplants by donor type.").

$32 I d$. (To find current numbers, follow "National data", "select report, choose category, transplant", "choose organ, all", "transplants by donor type", "change report, heart, lung, intestine, and pancreas.").

33 Jon Diesel, Do Economists Reach a Conclusion on Organ Liberalization?, 7 J. AM. Inst. ECON. RES. 320, 322 (Sept. 2010) (discussing how the growth of the organ waiting list has resulted in "expanded criteria" for procuring cadaver organs), available at http://econjwatch.org/articles/do-economists-reach-a-conclusion-onorgan-liberalization [http://perma.cc/4YK8-XXVV]. 
used in transplants. ${ }^{34}$ The recipients of these organs have, in some rare cases, developed cancer as a consequence of receiving the organs.35 Another problem caused by the shortage is poor quality genetic matches between the organ and the recipient. A better match, unsurprisingly, decreases the likelihood of the recipient's body rejecting the new organ. ${ }^{36}$ The organ shortage means people have to linger in the organ queue for an average of three to five years. ${ }^{37}$ The patient's health is deteriorating during this time and may render a patient ineligible for an organ. ${ }^{38}$ Therefore, an organ alternative or a way to increase the supply of human organs is needed.

\section{Possible SoluTIONS}

Outside of a market for human organs, a few solutions exist to alleviate the organ shortage. Technological advances will help alleviate the organ shortage one day. Preventative healthcare is another way to reduce the organ shortage. Presumed consent is a policy successfully used by some countries to increase the organ supply. Addition-ally, donor

34 Can I Donate My Organs If I've Had Cancer, AM. CANCER Soc'y, http://www.cancer.org/treatment/survivorshipduringandaftertreatment/ can-i-donate-my-organs [http://perma.cc/V7HX-X7GE] (last visited Nov. $6,2015)$.

35 Id.

36 Christoph Frohn et al., The Effect of HLA-C Matching on Acute Renal Transplant Rejection, 16 NEPHROLOGY DIALYSIS TRANSPLANTATION 355 , 355 (2001) (discussing the desirability of immunologically compatible despite the immunosuppressive drugs), available at http://ndt.oxfordjournals.org/content/16/2/355.full [http://perma.cc/ LFU5-HXVX].

37 The Waiting List, KIDNEY LINK, http://www.kidneylink.org/ TheWaitingList.aspx [http://perma.cc/LRN8-2NH8] (last visited Nov. 6, 2015).

38 Glossary, Organ Procurement and Transplantation Network, http://optn.transplant.hrsa.gov/resources/Glossary\#A [http://perma.cc/ T6R7-T2HZ] (last visited Nov. 6, 2015). 
pairing schemes are posited as a way to help reduce the organ shortage. Each of these options is discussed below.

\section{A. Technology}

Stem cells are immature cells and have the ability to become any of the body's specialized cells. ${ }^{39}$ The ability of stem cells to transform into any of the body's cells leads scientists and medical professionals to believe stem cells may be able to cure a medley of health problems. ${ }^{40}$ For over twenty years, stem cells have been used in bone marrow transplants to help recipients produce healthy white blood cells. ${ }^{4}$ In 2013, scientists grew a "mini-kidney."42 This occurrence was the first time researchers have been able to produce a functioning kidney with stem cells. ${ }^{43}$

Although stem cell research has the potential to solve the organ shortage, the technology is likely over a decade away. ${ }^{4}$ Stem cell research is also controversial; however, most of the debate surrounds embryonic stem cell research. The Catholic Church has no qualms with stem cells obtained licitly,

${ }^{39}$ Stem Cell Basics, NAT'L Inst. HEALTH, http://stemcells.nih.gov/info/ basics/pages/basics1.aspx [http://perma.cc/ZW27-PG8M] (last visited Nov. 30, 2015).

40 The Power of Stem Cells, California Inst. For Regenerative MED., https://www.cirm.ca.gov/patients/power-stem-cells [https:// perma.cc/F7QZ-UB4V] (last updated Jan. 2015).

41 Theodore Moore et. al., Bone Marrow Transplantation, MEDSCAPE, http://emedicine.medscape.com/article/1014514-overview [https:// perma.cc/SEF8-4AWS] (last updated Nov. 7, 2014).

42 Jonathan Pearlman, Kidney Grown from Stem Cells by Australian Scientists, THE TELEGRAPH (Dec. 16, 2013, 10:28 AM), http:// www.telegraph.co.uk/news/worldnews/australiaandthepacific/australia/ 10520058/Kidney-grown-from-stem-cells-by-Australian-scientists.html [http://perma.cc/6G7B-ADVG].

${ }_{43} I d$.

44 The Associated Press, Lab-grown Organs Might Be Solution to Transplant Woes, N. Y. DAILY NeWs (June 17, 2013, 2:22 PM), http://www.nydailynews.com/life-style/health/scientists-work-groworgans-transplants-article-1.1374818 [http://perma.cc/M5P5-2DQ5]. 
meaning without destroying human life. ${ }^{45}$ The issue presented by embryonic stem cell research is the same issue presented by abortion: When does life begin? The Vatican's statement on the question is, "from the moment the zygote has formed, [it] demands the unconditional respect that is morally due to the human being in his bodily and spiritual totality." 46 Embryonic stem cell research results in the death of embryos, viewed as whole persons by the Catholic Church and many others. ${ }^{47}$ Opponents believe the benefits that may result are outweighed by the destruction of life caused by the stem cell research. ${ }^{48}$

Cloning has potential to solve the organ shortage but presents many of the same issues as stem cell research. There are a variety of different types of artificial cloning. Therapeutic cloning is the type most pertinent to the organ shortage as researchers hope to grow organs to replace diseased ones. ${ }^{49}$ Indeed, in 2014, stem cells were cloned and now offer the prospect for new transplant operations. ${ }^{50}$ As

45 William Card. Levada \& Luis F. Ladaria, S.I., Congregation for the Doctrine of the Faith: Instruction Dignitas Personae on Certain Bioethical Questions, THE VATICAN (June 20, 2008), http:// www.vatican.va/roman_curia/congregations/cfaith/documents/rc_con_cfa ith_doc_20081208_dignitas-personae_en.html [http://perma.cc/VB5ZHLHN].

46 Id.

47 Nancy Frazier O'Brien, Embryonic Stem-Cell Research Immoral, Unnecessary, Bishops Say, AM. CATHOLIC, http:// www.americancatholic.org/News/StemCell/ [https://perma.cc/UM3HTSLG] (last visited Feb. 4, 2016).

48 Id. See also Embryonic Stem Cell Research: An Ethical Dilemma, EUROSTEMCELL, http://www.eurostemcell.org/factsheet/embryonic-stemcell-research-ethical-dilemma [https://perma.cc/Y2PX-3SPE] (last updated Nov. 5, 2015).

49 Cloning, Nat'L Human Genome Research Inst., http:// www.genome.gov/25020028\#al-3 [http://perma.cc/SBN7-86V7] (last updated June 11, 2015).

50 Sarah Knapton, Breakthrough in Human Cloning Offers New Transplant Hope, THE TELEGRAPH (Apr. 17, 2014, 8:04 PM), http:// www.telegraph.co.uk/news/science/science- 
therapeutic cloning involves stem cells, many of the same objections are raised against it. In fact, the Vatican condemns therapeutic cloning even more harshly than it reprimands reproductive cloning. ${ }^{51}$ Therapeutic cloning results in the destruction of stem cells, and the Vatican asserts, "It is gravely immoral to sacrifice a human life for therapeutic ends." 52

A new technology offering a solution to the organ shortage is bioprinting, a form of $3 \mathrm{D}$ printing. To provide a very crude description of bioprinting, the 3D printer uses an "ink" composed of cells and a base, usually a hydrogel but sometimes collagen. ${ }^{53}$ Layers of the designed structure are printed atop one another producing the desired design. ${ }^{54}$ Bioprinting is already being used to create various bone implants. ${ }^{55}$ Although functioning organs have not been produced yet, organ prototypes have been successfully bioprinted. ${ }^{56}$ The adaptability of stem cells makes their use appealing in bioprinting; 57 however, the use of stem cells, as previously stated, presents ethical issues. Furthermore, 3D printing functional organs is likely decades away. ${ }^{58}$ Therapeutic cloning is in its early stages, so creating functional organs through this means is also likely many

news/10774097/Breakthrough-in-human-cloning-offers-new-transplanthope.html [http://perma.cc/4WN9-HDTH].

51 Card. Levada \& Ladaria, S.I., supra note 45.

52 Id.

53 Lyndsey Gilpin, 3D 'Bioprinting': 10 Things You Should Know About How It Works, TechRePUBlic (Apr. 23, 2014, 4:00 AM), http://www.techrepublic.com/article/3d-bioprinting-10-things-you-

should-know-about-how-it-works/ [http://perma.cc/FG85-HBN5].

54 Id.

55 Sarah Butler, Medical Implants and Printable Body Parts to Drive $3 D$ Printer Growth, The Guardian (Aug. 24, 2014), http:// www.theguardian.com/business/2014/aug/24/medical-implants-drive-3dprinter-growth [http://perma.cc/VV8K-KTEM].

56 Gilpin, supra note 53.

57 Id.

58 Butler, supra note 55. 
years away. ${ }^{59}$ A more immediate solution to the organ shortage is needed.

\section{B. Presumed Consent}

Presumed consent involves changing the law to classify a decedent as a potential organ donor unless that individual had manifested opposition to donation prior to death. ${ }^{60}$ Legislation, in favor of presumed consent, will almost certainly increase the number of organs available for transplantation. ${ }^{61}$ Hence, Spain, often regarded as the model presumed consent nation, has the highest cadaver organ procurement rate in the world. ${ }^{62}$

The Spanish presumed consent model relies heavily on donor coordinators, of which it has many-at least one in each hospital. ${ }^{63}$ Spanish donor coordinators utilize techniques to identify potential donors then attempt to develop a relationship with the donor's family. ${ }^{64}$ Spain also reimburses hospitals for the organ donors they provide. ${ }^{65}$ In addition to this, education and advertising are part of the Spanish

59 Vicki Glaser, Progress in Stem Cell Pluripotency, GEN (Jan. 15, 2014), http://www.genengnews.com/gen-articles/progress-in-stem-cellpluripotency/5115/?page $=2$ [https://perma.cc/96FQ-M3L3].

60 Alberto Abadie \& Sebastien Gay, The Impact of Presumed Consent Legislation on Cadaveric Organ Donation: A Cross-Country Study, $25 \mathrm{~J}$. HEALTH \& ECON. 599, 600 (2006) (defining presumed consent), available at http://www.hks.harvard.edu/fs/aabadie/pconsentp.pdf [http:// perma.cc/BC7D-YNQ9].

61 Simon Bramhall, Presumed Consent for Organ Donation: A Case Against, 93 ANN. R. ColL. SuRG. ENGL. 268, 272 (2011) (stating presumed consent seems like a sure way to increase the organ supply), available at http://www.ncbi.nlm.nih.gov/pmc/articles/PMC3363073/pdf/rcse9304270.pdf [http://perma.cc/R73N-53TD].

62 Rafael Matesanz et. al., Spanish Experience as a Leading Country: What Kind of Measures Were Taken? 24 TRANSPLANT INT'L 333, 334 (2011), available at http://onlinelibrary.wiley.com/doi/10.1111/j.14322277.2010.01204.x/epdf [http://perma.cc/EUT9-2DGQ].

63 Bramhall, supra note 61 , at 270-71.

64 Id. at 271.

$65 I d$. 
model. 66 The Spanish model has been replicated with success in Italy, implying other nations can adopt the model with similar results. ${ }^{67}$

Presumed consent has a practicality to it. The dead have no use for their organs, and those with disease can benefit tremendously from the organs. Presumed consent has a high social utility; however, presumed consent does not always work. Sweden has adopted presumed consent but has seen no change in its cadaver organ donation rate. ${ }^{68}$ Moreover, the citizens of Brazil and France vehemently opposed the introduction of presumed consent. ${ }^{69}$ The result of attempted presumed consent legislation was an aversion to organ donation in the two countries. ${ }^{70}$

Although Spain is heralded as the exemplar of a presumed consent regime, the Spanish model does not rely on presumed consent for its success. ${ }^{71}$ Spanish physicians can legally harvest a decedent's organs without a family's consent, but doctors usually respect the wishes of the family. ${ }^{72}$ Spanish procurement officials are financially rewarded based on the number of donors they recruit, ${ }^{73}$ and one assumes monetary incentives affect procurement performance regardless of the law. Perhaps most importantly, the Spanish system offers payments to the decedent's family for funeral expenses. ${ }^{74}$ Despite Spain's efforts, the waiting list for kidney transplants in Spain has not been substantially reduced since presumed consent was implemented. ${ }^{75}$

66 Id.

67 Id.

$68 I d$.

69 Id.

$70 \mathrm{Id}$.

71 T. Randolph Beard Et al., The Global Organ Shortage 43 (2013).

72 Id.

73 Id.

$74 \mathrm{Id}$.

75 Ghods \& Savaj, supra note 9 at 1144 (discussing the success that the Spanish model has had with increasing the number of organs 
Presumed consent presents legal and ethical problems for the United States. It implies the government owns people at the moment of their death, and this is antithetical to the common law tradition that an individual's rights exist even after death. ${ }^{76}$ The government claiming dominion over the bodies of the deceased would likely constitute a taking under the Fifth Amendment and require just compensation. This raises the issue of whether the government would be violating NOTA, as it would be providing compensation for the decedent's body when NOTA forbids exchanging valuable consideration for human organs. ${ }^{77}$ First Amendment religious liberty issues are also likely to arise if presumed consent is implemented in the United States. In any event, over $99 \%$ of deaths do not provide transplantable organs, ${ }^{78}$ so a different solution to the organ shortage must be sought.

\section{Prevention}

Most people on the organ waiting list are there because of preventable disease. Over $80 \%$ of Americans waiting for an organ are in line for a kidney. ${ }^{79}$ Diabetes is the leading cause of kidney failure in the United States accounting for $43.7 \%$ of cases, ${ }^{80}$ and the vast majority of diabetics have type 2

available, but stating that the increase has done little to reduce the shortage).

76 Daniel Hannan, Inventing Freedom 141 (2013).

7742 U.S.C. $\S 273 \mathrm{e}(\mathrm{a})$ (2015).

78 Fry-Revere, supra note 7.

79 Data, supra note 25. (To see current information, follow "data", "national data", "select report, choose category, waiting list", click "candidates", and "overall by organ." Divide the kidney total by all organs to arrive at the percentage.)

80 High Blood Pressure and Kidney Disease, NAT'L Inst. DiabeTEs \& Digestive \& KIDNEY DisEASES, http://kidney.niddk.nih.gov/ KUDiseases/pubs/highblood/ [http://perma.cc/J4MQ-6UP7] (last visited Nov. 30, 2015). 
diabetes (roughly 27.85 million of the 29.1 million cases). 81 High blood pressure is the second leading cause of kidney disease accounting for $28.4 \%$ of kidney disease in the United States. ${ }^{82}$ Diet, exercise, maintaining a healthy bodyweight, limiting alcohol consumption, and not smoking can often prevent high blood pressure and type 2 diabetes. ${ }^{83}$ Following these guidelines can also help prevent the need for liver, heart, and other organ transplants.

Although the solution is simple, government attempts to promote healthier lifestyles will likely meet with controversy in the United States. The Affordable Care Act ("ACA") requires health insurance plans to cover counseling for obesity $^{84}$ and a myriad of other "free" preventive health services. ${ }^{85}$ Recent polling data shows a majority of Americans disapprove of the ACA.86 Moreover, the ACA's future is uncertain as congressional republicans continue their effort to repeal it. 87

81 See Statistics About Diabetes, Am. Diabetes Ass'N (June 10, 2014), http://www.diabetes.org/diabetes-basics/statistics/ [http://perma.cc/ 5XGC-CUGL].

82 High Blood Pressure and Kidney Disease, supra note 80.

83 Preventing High Blood Pressure: Healthy Living Habits, CTR. FOR Disease CONTROL \& PREVENTION, http://www.cdc.gov/bloodpressure/ healthy_living.htm [http://perma.cc/LV68-NKH8] (last updated July 7, 2014).

84 Watch Your Weight, HEALTHFINDER.GOV, http://healthfinder.gov/ HealthTopics/Category/health-conditions-and-diseases/diabetes/watchyour-weight\#take-action_5 [http://perma.cc/9ZZ5-R7W9] (last updated Sept. 23, 2015).

85 Preventive Health Services for Adults, HealthCARE.GOv, https:// www.healthcare.gov/preventive-care-benefits/ [https://perma.cc/2QLLC9MW] (last visited Nov. 30, 2015).

86 Public Approval of Health Care Law, REALCleAR Politics, http:// www.realclearpolitics.com/epolls/other/obama_and_democrats_health_c are_plan-1130.html [https://perma.cc/7R4W-W7BL] (last visited Feb. 8, 2016).

87 Jordan Fabian, Obama Vetoes Health Bill Repeal, THE HiLl (Jan. 8, 2016), http://thehill.com/homenews/administration/265078-obamavetoes-healthcare-bill-repeal [https://perma.cc/RX7F-2PMF]. 
The American aversion to the ACA is symbolic of Americans opposition to government interference with their private health choices. Former New York City Mayor Michael Bloomberg's proposed soft drink ban was supported by only $36 \%$ of the City's residents. 88 First Lady Michelle Obama's campaign to encourage healthier lifestyles prompted high school students to blame her for their unappetizing lunches with the hashtag \#thanksmichelleobama. ${ }^{89}$

Ultimately, any public health policy's effectiveness is contingent on its acceptance by the targeted population. Americans do not seem eager to change their largely unhealthy lifestyles, so prevention, despite its effectiveness, is an unlikely solution to the organ shortage.

\section{Facilitate Living Donation}

One way of facilitating organ donation is through paired organ donation. Paired donation works by matching an incompatible donor/recipient pair with another incompatible donor/recipient pair. More than two groups of people can be involved in the exchange. Donor exchanges enable patients to get organs their bodies are more likely to accept. As paired donation operates via market mechanism, that is trading an incompatible kidney for a compatible kidney, it raises many of the same ethical questions as monetary purchases of organs. ${ }^{90}$ Congress passed the Charlie W. Norwood Living

88 Michael M. Grynbaum \& Marjorie Connelly, 60\% in City Oppose Bloomberg's Soda Ban, Poll Finds, The N.Y. Times (Aug. 22, 2012), http://www.nytimes.com/2012/08/23/nyregion/most-new-yorkers-opposebloombergs-soda-ban.html [http://perma.cc/AS5Z-TFQZ].

89 Laura Mandaro, Teens Tweet Gross Lunches, Say \#thanksmichelleobama, USA TODAY (Nov. 22, 2014, 9:52 PM), http:// www.usatoday.com/story/news/nation-now/2014/11/22/

thanksmichelleobama-school-lunches-pictures-twitter/ 19415567/ [http:// perma.cc/T6HP-3A5V].

90 Sam Crowe et al., Increasing the Supply of Human Organs: Three Policy Proposals, The President's Council on Bioethics (2007), 
Organ Donation Act in 2007 clarifying that paired donation does not violate NOTA. ${ }^{91}$ Since the Act's passage, the kidney waiting list has grown implying paired donation is not the solution to the organ shortage. This is not surprising because barter is an inefficient method of allocating resources. ${ }^{92}$

Another way of increasing the number of living donors is to make donation less burdensome. Traveling and time spent getting evaluated for donation can be expensive. Medical professionals recommend eight weeks for recovery post donation. ${ }^{93}$ During this period, the donor still has to pay rent and other expenses, so even the most willing of donors may not be able to afford to donate. The organ recipient can reimburse donors for some of these expenses; however, only recipients with sufficient wealth can afford to do this. ${ }^{94}$ A government program, the National Living Donor Assistance Center, provides up to $\$ 6,000$ of pre-transplant expenses for those living with an income of $300 \%$ of the poverty level or below. ${ }^{95}$ Insurance or another program may help those with incomes above this level during the pre-transplant phase. Aside from medical care, donors receive little help posttransplant.

https://bioethicsarchive.georgetown.edu/pcbe/background/increasing_su pply_of_human_organs.html [https://perma.cc/9CFD-QXYQ].

91 Charlie W. Norwood Living Organ Donation Act, Pub. L. No. 110144, 121 Stat. 1813 (2007).

92 Gary S. Becker \& Julio J. Elias, Cash for Kidneys: The Case for a Market for Organs, THE WALL ST. J., http:// www.wsj.com/articles/SB100014240527023041494045793225600048171 76 [http://perma.cc/ZGP8-WASA] (last updated Jan. 18, 2014, 4:58 PM) [hereinafter Cash for Kidneys].

93 FAQ: Living Kidney Donor, UnIV. California SAN Francisco MED. CTR., http://www.ucsfhealth.org/education/living_kidney_donor/ \#24 [http://perma.cc/Z3HU-5U2L] (last visited Nov. 30, 2015).

94 Crowe et al., supra note 90.

95 Nat'l Living Donor Assistance Ctr., Living Organ Donors: Assistance with Travel, Lodging and Meals, available at https:// www.livingdonorassistance.org/documents/NLDAC_Program_Brochure. pdf [https://perma.cc/QN2N-TCSR] (last visited Nov. 30, 2015). 
Enabling charities, private individuals, or the government to provide financial assistance to donors makes sense. The American Living Organ Donor Fund ("ALODF") is a private charity that helps donors with postoperative expenses, ${ }^{96}$ but the ALODF is operating in a legal gray area due to NOTA's prohibition on offering "valuable consideration" in exchange for human organs. Over a dozen states provide tax incentives to facilitate donations of organs and marrow; nevertheless, these state tax breaks have not increased donation rates. ${ }^{97}$ Although payment for organs is illegal, donors should not suffer financially in the aftermath of their beneficent act.98 Reducing the economic strain of donors will increase donations, but probably will not end the organ waiting list.

\section{ORGAN MARKET ETHICAL ISSUES}

Perhaps the most obvious solution to the organ shortage is creating a market for human organs. Basic economics states if the price of a good increases more people will be willing to supply the good.99 The concept is so natural that soon after antirejection drugs enabled transplants to occur between diverse peoples an international organ market was proposed. ${ }^{100}$ Under the proposal, Americans would be allowed to purchase the organs of impoverished citizens of

96 Mission, AM. LIVING ORGAN DONOR FUnD, http:// www.helplivingdonorssavelives.org/about-us/our-mission/ [http://perma.cc/C2GJ-JMAJ] (last visited Nov. 30. 2015).

97 Tax Incentives and Organ Donation, AM. Transplant Found.

(Nov. 15, 2012), http://www.americantransplantfoundation.org/2012/ 11/15/tax-incentives-and-organ-donation/ [http://perma.cc/6HCN-8NRY].

98 Mission, supra note 96.

99 Al Ehrbar, Supply, LIBRARY ECON. \& LIBERTY (2008), http://www.econlib.org/library/Enc/Supply.html [http://perma.cc/3QERWSAK].

100 Susan Hankin Denise, Regulating the Sale of Human Organs, 71 Va. L. Rev. 1015 (1985) (discussing Barry Jacobs' proposed organ market). 
the Third World. 101 Public outrage prompted NOTA, and its prohibition on organ sales. ${ }^{102}$ Virtually every country has banned the organ trade. ${ }^{103}$ Countless organizations including the United Nations, 104 American Medical Association ("AMA"), 105 and the Catholic Church ${ }^{106}$ have condemned the market for human organs.

Underlying most objections to the organ market are principles of fairness and corruption. The fairness argument is premised on the notion that people are entering the market with unequal bargaining power; therefore, one party has the ability to unduly coerce the other. ${ }^{107}$ Accordingly, true mutual consent cannot be obtained in the transaction. ${ }^{108}$ For example, the wealth gap between the richest and poorest Americans prevents a fair exchange between the groupsespecially for something as important an organ. The fairness objection is amplified by the possibility of wealthy citizens

101 Id. at 1022 .

102 Id. at 1023-24.

103 Lisanne Denneman \& Marianne Mol, Organ Trade: A Win-Win Situation or Exploitation in Disguise?, GLOBAL MED. 19 (Nov. 2010), http://e.issuu.com/embed.html\#10443465/30247857 [http://perma.cc/ 3AJT-B3RJ].

104 Arthur Caplan et al., Trafficking in Organs, Tissues and Cells and Trafficking in Human Beings for the Purpose of the Removal of Organs, Joint Council Europe/United NATIONS STUdY 30 (2009), http:// www.coe.int/t/dghl/monitoring/trafficking/Docs/News/OrganTrafficking study.pdf [http://perma.cc/K97R-SGD5].

105 Opinion 2.15-Transplantation of Organs from Living Donors, AM.

MED. Ass'N, http://www.ama-assn.org/ama/pub/physician-resources/ medical-ethics/code-medical-ethics/opinion215.page

[http://perma.cc/3SW5-K2TG] (last updated June 2011).

106 Pope John Paul II, Address of the Holy Father John Paul II to the 18th International Congress of the Transplantation Society (Aug. 29, 2000), http://w2.vatican.va/content/john-paul-ii/en/speeches/2000/jul-sep/ documents/hf_jp-ii_spe_20000829_transplants.html

[http://perma.cc/TP9R-JDSX].

107 Michael J. Sandel, What Money Can't Buy: The Moral Limits of Markets, The Tanner LeCtures on Human Values 112 (May 11-12, 1998), http://tannerlectures.utah.edu/_documents/a-to-z/s/sandel00.pdf [http://perma.cc/3AGQ-7NKN].

108 Id. 
from around the globe purchasing organs from poor denizens of the world's most impoverished nations. The living standards are so vastly different in some countries that citizens of wealthy countries can basically purchase organs for free. ${ }^{109}$ If the organ market is legalized, proponents of the fairness argument fear the rich will come to view the poor as organ banks. 110

Corruption is the other morality-based argument made by organ market opponents. The corruption argument asserts some things should not be commoditized because putting a price on a thing diminishes it.111 Human organs are considered by some opponents of an organ market to be outside the commercial sphere and should be treated exclusively as gifts. ${ }^{112}$ Following the Kantian tradition, treating organs as commodities diminishes the inherent dignity of human beings by treating people as a means rather

109 GDP Per Capita, THE WoRLD BANK, http://data.worldbank.org/ indicator/NY.GDP.PCAP.CD?order=wbapi_data_value_2014+wbapi_dat a_value+wbapi_data_value-last\&sort=asc. Gross domestic product per capita can serve as a proxy for average annual income in a country. Using United States dollars, World Bank data shows Malawi had the lowest GDP per capita in 2014 at $\$ 255$ and Luxembourg had the highest GDP per capita at $\$ 116,664$. 3 . This means Malawi's average GDP per capita is less than one percent of the average Luxembourg citizen's GDP per capita. Consequently, a wealthy individual from Luxembourg can spend less than one percent of her annual income on a kidney from a Malawian, and this transaction would result in the Malawian exceeding his annual income. This is particularly true if the Malawian is poor by the country's standards.

110 Brian Resnick, Living Cadavers: How the Poor Are Tricked Into Selling Their Organs, THE ATLANTIC (Mar. 23, 2012), http:// www.theatlantic.com/health/archive/2012/03/living-cadavers-how-thepoor-are-tricked-into-selling-their-organs/254570 [http://perma.cc/ 4GJW-LW4E].

111 Sandel, supra note 107, at 112.

112 Julia D. Mahoney, Altruism, Markets, and Organ Procurement, 72 Law \& Contemp. Probs. 17, 17 (2009), available at http:// scholarship.law.duke.edu/cgi/viewcontent.cgi?article=1535\& context=lcp [http://perma.cc/QV2A-QMCF]. 
than an end. ${ }^{113}$ Pope John Paul II aligned himself with Kant by stating, "any procedure which tends to commercialize human organs or to consider them as items of exchange or trade must be considered morally unacceptable, because to use the body as an 'object' is to violate the dignity of the human person."114 Aside from devaluing life, opponents of organ markets assert organ selling violates the medical principle of "do no harm" because extracting an organ harms the provider purely for commercial reasons. ${ }^{115}$

Nonetheless, some who assert that exchanging money for organs is unacceptable would permit certain forms of nonmonetary compensation for donors. Suggested nonmonetary rewards for donation include a donor medal-ofhonor and insurance coverage. ${ }^{116}$ Interestingly, reimbursing donors for funeral expenses also constitutes a nonmonetary incentive. 117 A small amount, $\$ 300$, is considered a sign of appreciation and not a payment; plus, the payment is made after the donor's death. ${ }^{118}$ The difference between these signs of appreciation and money are symbolic, but organ market opponents think symbols matter. ${ }^{119}$ The distinction between

113 Susan M. Shell, Chapter 13: Kant's Concept of Human Dignity as a Resource for Bioethics in Human Dignity and Bioethics: Essays Commissioned by The President's Council on Bioethics, THE PREsIDENT'S COUNCIL ON BIOETHICS (Mar. 2008), https:// bioethicsarchive.georgetown.edu/pcbe/reports/human_dignity/

chapter13.html [http://perma.cc/PNW9-LJB3].

114 Pope John Paul II, supra note 106.

115 Arthur Caplan, Chapter 28: Organ Transplantation in From Birth to Death and Bench to Clinic: The Hastings Center Bioethics Briefing Book for Journalists, Policymakers, and Campaigns, THE HAsTINGs CTR. 131 (2008), http://www.thehastingscenter.org/uploadedFiles/ Publications/Briefing_Book/organ\%20transplantation\%20chapter.pdf [http://perma.cc/RQB7-FL2Y].

116 Francis L. Delmonico et al., Ethical Incentives-Not Paymentfor Organ Donation, 346 N. ENGL. J. MED. 2002, 2003 (2002), a vailable at http://eml.berkeley.edu/ webfac/held/delmonico.pdf

[http://perma.cc/55VV-TCW6].

117 Id.

118 Id.

119 Id. at 2004. 
expressing gratitude for an organ and buying the organ is analogous to giving a friend a bottle of wine as thank you versus handing him cash. ${ }^{120}$

Appeals to fairness and corruption neither alleviate the organ shortage, nor do they benefit the people prohibition is supposed to protect. These concerns both hinge in part on the possibility of exploitation of the poor resulting from the coercive purchasing power of the rich. Financial pressure affects the poor more than the rich making it unfair, and coercion violates the individual's humanity by disrupting his free will. However, objections based on financial pressure are almost entirely irrelevant in a market for cadaver organs, as the dead cannot be coerced. People vend organs to improve their earthly lives rather than to gain rewards in the afterlife. In the organ market, financial coercion arises from discrepancies in wealth in favor of the buyer. What if the script is flipped and billionaire Bill Gates wants to sell his kidney to a poor Pakistani? Similarly, what if people with equivalent levels of wealth want to enter a transaction for a kidney? Objections to the organ market premised on monetary coercion are more difficult to sustain when the playing field is leveled or tilted in the other direction.

If a market for human organs is legalized, it seems probable that the majority of organ sellers will be poor. ${ }^{121}$ However, barring an activity is not justified simply because a majority of people participating in the activity are poor. The indigent shine shoes, mine coal, and engage in various other trades that the rich do not because they are poor. ${ }^{122}$

120 Id.

121 Gary S. Becker \& Julio Jorge Elias, Introducing Incentives in the Market for Live and Cadaveric Organ Donations, 21 J. ECoN. PeRsPeCtives 3, 21 (2007) (discussing criticisms of an organ market), available at http://citeseerx.ist.psu.edu/viewdoc/ download?doi=10.1.1.335.4572\&rep=rep1\&type=pdf [http://perma.cc/ 5QKE-ZGAA] (hereinafter Introducing Incentives).

122 Sunny Woan, Buy Me a Pound of Flesh: China's Sale of Death Row Organs on the Black Market and What Americans Can Learn from It, 47 SANTA ClARA L. REV. 413, 439 (2007). 
Prohibiting opportunities to earn money does not improve the condition of those in poverty. An additional point to consider regarding kidney sales is 3 of 10,000 living kidney donors die during the operation, ${ }^{123}$ Accordingly, death during a kidney removal operation is lower than the risk of death in common occupations like refuse collector $(3.58$ per 10,000$)$ and roofer (4.62 per 10,000).124 The risk of death during kidney donation is substantially lower than the risk of death in the legal commercial fishing industry, which has an annual fatality rate of 12.4 per 10,000 workers. ${ }^{125}$ Divers and those employed in various other occupations receive additional pay for taking on jobs that pose high risks to their health. ${ }^{126}$ Preventing people from choosing what risks are acceptable in their quest to earn a living is "paternalism in its worst form."127

Although shielding the poor from abuse by the wealthy is a purpose of prohibiting organ sales, prohibition has created the black market. ${ }^{128}$ A summit representing numerous organizations that oppose the sale of human organs acknowledged that the shortage of organs, caused at least in part by prohibition, has led to undesirable and unethical

123 Living Donors, NAT'L KIDNEY REGISTRY, http:// www.kidneyregistry.org/living_donors.php?cookie=1 [http://perma.cc/ U8EL-KLLF] (last visited Nov. 30, 2015).

124 BUREAU OF LABOR STATISTICS, NAT'L CENSUS OF FATAL OCCUPATIONAL INJURIES IN 2014 (PRELIMINARY RESUlTS) 4 (Sep. 17, 2015), http://www.bls.gov/news.release/pdf/cfoi.pdf [http://perma.cc/ ABP8-M7SF].

125 Commercial Fishing Safety, Ctr. Disease Control \& PREVENTION, http://www.cdc.gov/niosh/topics/fishing/ nationaloverview.html [https://perma.cc/5TRN-JSDE] (last updated Oct. 28,2014 ).

126 J. Savulescu, Is the Sale of Body Parts Wrong?, 29 J. MED. ETHICS 138, 139 (2003), available at http://jme.bmj.com/content/29/3/ 137.full.pdf+html [http://perma.cc/LNN2-JANS].

127 Id.

128 The black market is discussed in greater depth in the following section. The cursory discussion occurring here is simply to an answer an objection to the organ market rather than provide a thorough analysis of the black market. 
outcomes such as the black market. ${ }^{129}$ All of the legal organ market opponents' worst fears are happening in the underground trade of human organs, and are caused by prohibition. ${ }^{130}$ People from wealthy countries routinely purchase organs (usually kidneys) from impoverished citizens of the Third World. ${ }^{131}$ Black market transactions are often exploitative and make the transplant process itself extra risky. ${ }^{132}$ Seller health erodes substantially after black market operations. ${ }^{133}$ Buyers are at high risk of contracting diseases like HIV and have much lower survival rates than when transplants are performed in a proper medical environment. ${ }^{134}$

129 The Declaration of Istanbul on Organ Trafficking and Transplant Tourism, The Transplantation SOC'Y \& InT'L SOC'Y NEPHROlOGY 1 (Apr. 30-May 2, 2008), http://multivu.prnewswire.com/mnr/ transplantationsociety/33914/docs/33914-Declaration_of_Istanbul-

Lancet.pdf [http://perma.cc/N7C7-XLUZ].

130 Dominique Martin, Medical Travel and the Sale of Human Biological Materials: Suggestions for Ethical Policy Development, 10 GLOBAL SOC. POL'Y 377, 385 (2010) (noting that prohibition likely causes the ethical problems banning organ sales is supposed to prevent).

131 Nancy Scheper-Hughes, Parts Unknown: Undercover Ethnography of the Organs-Trafficking Underworld, 5 ETHNOGRAPHY 29, 33 (2004), available at http://www.uky.edu/ tmute2/ geography_methods/readingPDFs/scheper-hughes-PartsUnknown.pdf [http://perma.cc/JR3K-BBKF] (discussing how transplant technology has spread to the developing world and how the poor have become a source of organs for the privileged).

132 L D de Castro, Commodification and Exploitation: Arguments in Favour of Compensated Organ Donation, 29 J. MED. ETHICs 142, 145 (2003), available at http://jme.bmj.com/content/29/3/142.full.pdf+html [http://perma.cc/QQW9-WGXX] (discussing how prohibiting organ sales does not protect those who are participating in illegal organ operations).

133 Vivekanand Jha, Paid Transplants in India: The Grim Reality, 19 NEPHROLOGY DiAlYsis TRANSPLANTATION 541, 542 (2004), available at http://ndt.oxfordjournals.org/content/19/3/541.full.pdf+html [http:// perma.cc/LQG3-R77L].

134 David B. Samadi, Consequences of the Rise of Illegal Organ Trafficking, Fox NEWs (May 30, 2012), http://www.foxnews.com/ health/2012/05/30/consequences-rise-in-illegal-organ-trafficking/ [http://perma.cc/LQG3-R77L]. 
The ghoulish outcomes produced by the black market are nonexistent in proper clinical settings. Parting with a kidney should present the same risk regardless of whether the kidney is available because of charitable or commercial motives, because the procedure is the same regardless of the organ provider's motivation. Kidney donation is a fairly safe procedure. In fact, Johns Hopkins Medicine states "donors tend to do as well or better than the general population in regard to long term medical complications." 135 The legality of donation allows donors to receive proper medical care post operation. When things go poorly during donation, the law provides recourse to donors. This grants donors protection from medical mishaps. Furthermore, donors must undergo a screening process to legally donate an organ. ${ }^{136}$ The black market has no such vetting process; hence, the vulnerable are at much greater risk of predation in illicit organ transactions. Accordingly, providing a legal framework for organ sales is the best way to prevent unfair transactions that exploit the poverty-stricken. ${ }^{137}$

Fairness may be a stated reason to prevent the organ market, but the impacts of the organ shortage are not fair. Minorities are more likely to suffer from kidney disease than

135 Karl Womer, What Kidney Donors Need to Know: Before, During, and After Donating a Kidney, Johns Hopkins MeD. Comprenensive TRANSPLANT CTR., http://www.hopkinsmedicine.org/transplant/news_events/media/transcri pts/kidney_pancreas/what_kidney_donors_need_to_know.html [http://perma.cc/AML3-P4SM] (last visited Nov. 30, 2015).

136 Donor Screening and Testing, CTR. Disease Control \& PREVENTION, http://www.cdc.gov/transplantsafety/ screening_testing.html [http:// perma.cc/4GVJ-34HJ] (last updated June 17, 2013).

137 J. Radcliffe-Richards et al., The Case for Allowing Kidney Sales, 351 THE LANCET 1950, 1951-52 (1998) available at http:// www.thelancet.com/journals/lancet/article/PIIS0140-6736(97)082111/fulltext [http://perma.cc/2F8M-5SVF] (asserting that exploitation is more likely to occur in illegal activities). 
whites. ${ }^{138}$ Blacks and Latinos are less likely to be placed on organ waitlists than whites because doctors do not refer nonwhites to transplant centers as frequently as physicians refer whites. ${ }^{139}$ Even assuming blacks and whites are placed in the kidney queue at the same time, blacks wait an average of $74 \%$ longer than whites to receive a kidney. 140 Interestingly, kidneys are the only organ that matching is a criteria rather than first-in-line status and medical need. ${ }^{141}$ Matching seems like a medically neutral criteria, but it has racially disparate impacts. A federal appellate court noted that people with diverse genes have a tougher time finding genetic matches, such as blacks who often have a "mix of African, Caucasian, and Native-American genes."142 In fact, blacks are only one-tenth as likely as whites to find a perfect match. ${ }^{143}$ Kidneys also happen to be the organ that blacks need most disproportionately to whites. ${ }^{144}$ Moreover, research indicates tissue matching is not an accurate predictor of transplant outcomes. ${ }^{145}$

The organ shortage not only causes treatment discrepancies based on race but also wealth and status. Money is not explicitly considered in organ distribution; nevertheless, a person with means has an advantage over those who lack resources. ${ }^{146}$ The rich can legally purchase

138 Race/Ethnicity and Kidney Disease, AM. KIDNEY Fund, http:// www.kidneyfund.org/are-you-at-risk/risk-factors/race-kidney-disease/ [http://perma.cc/2ZCG-WLHC] (last visited Nov. 30, 2015).

139 Michele Goodwin, Black Markets: The Supply and Demand OF BODY PARTS 90-91 (2006).

140 Id. at 96.

141 Id. at 97.

142 Flynn v. Holder, 684 F.3d 852, 857 (2011).

143 GoODWIN, supra note 139, at 103.

144 Id. at 97.

145 Matching and Compatibility, U.C. DAVIS HEALTH Sys., http://www.ucdmc.ucdavis.edu/transplant/livingdonation/donor_compati ble.html [http://perma.cc/C9LR-XKDP] (last visited Nov. 30, 2015).

146 Ray Hainer, Did Steve Jobs' Money Buy Him A Faster Liver Transplant?, CNN, http://www.cnn.com/2009/HEALTH/06/24/ 
billboards and other forms of publicity that the poor cannot, and the AMA deems donations resulting from public solicitation ethical. ${ }^{147}$ Advertising increases the advertiser's odds of receiving a directed organ donation, giving the rich an advantage over the poor in organ procurement. Wealthy citizens can also circumvent organ waiting lists by having residences in multiple states, and this enables wealthy individuals to be added to the organ waiting list in multiple jurisdictions. ${ }^{148}$ This gives the rich an advantage over the poor. ${ }^{149}$ Likewise, the rich can afford to engage in transplant tourism while the poor languish in organ queues because the poor lack the financial wherewithal to purchase organs on the black market.150 Regarding status, Pennsylvania Governor Robert Casey received a heart and liver transplant simultaneously within 24 hours of being placed on the wait list. ${ }^{151}$ Ethicists determined Casey did not receive preferential treatment, but his political office and wealth created the public perception that Casey benefitted from his status. ${ }^{152}$

The belief that the body is sacred and organ sales will corrupt its sanctity is a legitimate position. Convincing

liver.transplant.priority.lists/index.html?iref $=24$ hours

[http://perma.cc/86XY-RGJD] (last updated June 24, 2009, 11:29 AM).

147 Opinion 2.15-Transplantation of Organs from Living Donors, supra note 105.

148 Cash for Kidneys, supra note 92.

149 Judith Randal, Mantle's Transplant Raises Delicate Issues About Organ Allocation, 88 J. NAT'L CANCER INST. 484, 484 (1996), available at http://jnci.oxfordjournals.org/content/88/8/484.full.pdf [http://perma.cc/ NQA3-VDVR].

150 Henriette Johansen, Lebanon's Black Market in Refugee Organs, MidDlE E. MONITOR (Jan. 5, 2014, 8:52 PM), https:// www.middleeastmonitor.com/blogs/lifestyle/9067-lebanons-blackmarket-in-refugee-organs [http://perma.cc/ELT3-7DZC] (noting that rich Arabs fly to Beirut for transplants, even though buying organs is illegal. Presumably the poor are not doing this.).

151 Claudia Coates, Casey's Quick Transplant Renews Ethics Debate, L.A. Times (July 25, 1993), http://articles.latimes.com/1993-07-25/news/ mn-17587_1_heart-transplant [http://perma.cc/QS7L-QQZ7].

152 Id. 
someone with this position of the potential benefits of an organ market is unlikely. One assumes this objection is held in good faith; however, it is worth pointing out that opponents of kidney sales have bought organs. ${ }^{153}$ High minded positions are easy to take when the position holder is not the one suffering and staring death in the face. Furthermore, it is most peculiar that the medical personnel who perform the transplant are paid; the site of the transplant charges a fee; the organ recipient is able to exchange money for the gift of life; yet the person who makes the procedure possible-the organ provider-cannot be compensated without corrupting the procedure. ${ }^{154}$

In fact, current law allows a form of compensation to organ donors because paired organ donation is legal. 155 Paired donation is not considered corrupting, akin to the wine example above; rather, paired donation is considered altruistic. ${ }^{156}$ Professor Richard Epstein calls allowing paired donation while prohibiting purchases "baloney" because paired donation is a "market for barter." 157 There is no practical difference between a trade and a cash transaction. The purpose of the organ transaction is to save lives, so a market provides the most efficient mechanism for facilitating lifesaving organ transplants. ${ }^{158}$ Plus, money is provided as a

153 SigRID FrY-REVERE, THE KIDNEY SELLERS 95 (2014).

154 Charles A. Erin \& John Harris, An Ethical Market in Human Organs, 29 J. MED. ETHICS 137, 137 (2003), available at http:/l jme.bmj.com/content/29/3/137.full.pdf [http://perma.cc/8SA2-48ZE].

15542 U.S.C. $\$ 274 \mathrm{e}(\mathrm{a})(2015)$.

156 Richard Epstein, The Economics of Organ Donations: EconTalk Transcript, LIBRARY ECON. \& LIBERTY (June 5, 2006), http:// www.econlib.org/library/Columns/y2006/Epsteinkidneys.html

[http://perma.cc/RWT6-7VWM].

157 Id.

158 Nicholas Capaldi, A Catholic Perspective on Organ Sales, 6 CHRISTIAN BIOETHICS 139, 145 (2000), available at http:// www.ualberta.ca/ dcl3/Ref_2007-Aug17/commercialization\%20AND\%20health\%20policy\%200R\%20forecasti ng\%20etc/commercialization_body+parts_catholic+perspective.pdf [http://perma.cc/BF74-M7W7]. 
gift without denigrating the recipient in various situations such as birthdays, weddings, and baptisms. ${ }^{159}$ This may be why the AMA's Council for Ethical and Judicial Affairs has determined there is nothing inherently unethical about an organ market. 160

Although the law prohibits organ sales, sales occur and little is done to stop them. Sending people to jail who would not be alive but for the organ they illegally purchased strikes most people as unjust. Likewise, sending organ sellers to jail who have sacrificed their bodies so that another may live is equally deplorable. Organ market opponents may object to the market despite the seeming immorality of punishing market participants. Nevertheless, prohibiting the organ market is not practical. The law cannot stamp out all unseemly occurrences, so Thomas Aquinas believed the law should target actions that affect parties who do not consent to the activity like murder and rape. ${ }^{161}$ Aquinas would agree the black market in human organs is repugnant and desire its end. Determining an end is only half of the equationdevising a means to practically achieve the objective is the other half. ${ }^{162}$ The organ market opponent goal of preventing body defilement is best realized by creating a market where the rule of law governs transactions. This may be why Pope Pius XII left open the possibility of an organ market noting, "II]t would be going too far to declare immoral every acceptance or every demand of payment." 163

159 L D de Castro, supra note 132 (discussing the various situations when money is given as a gift or incentive).

160 Deborah Josefson, United States Starts to Consider Paying Organ Donors, 324 BRIT. MED. J. 446, 446 (2002), available at http:// www.ncbi.nlm.nih.gov/pmc/articles/PMC1172054/ [http://perma.cc/ A3GS-N3RS].

161 Thomas Aquinas, On LaW, Morality, and Politics 62 (William P. Baumgarth \& Richard J. Regan, 2d ed. 2002).

162 T. Hoffman, Aquinas on the Nature of Prudence, http:// faculty.cua.edu/hoffmann/courses/769_1081/769_Summary_2a2ae.47.pdf [http://perma.cc/8EH4-NWNJ] (last visited Nov. 30, 2015) (discussing prudence in action in $47.8 \mathrm{c}$ summary section).

163 Capaldi, supra note 158, at 141. 
Arguments based on fairness and corruption do not address the question of whether a market for organs would increase the supply of organs. Indeed, some opponents of organ markets assert providing financial compensation for organs would decrease the quantity, as well as the quality, of organs available for transplant. This theory is based largely on Richard Titmuss's 1971 study of the blood supply in England and the United States. ${ }^{164}$ During the period of Titmuss's observation, blood sales were illegal in the United Kingdom but legal in the United States. ${ }^{165}$ Titmuss found the quality and quantity of blood supply in the United Kingdom was superior to the blood supply in the United States. ${ }^{166}$ Titmuss concluded the American system leads to higher costs as well as greater risks of contaminated blood and chronic blood shortages. ${ }^{167}$

This prompted Titmuss to conclude Americans viewed blood as a commodity, so Americans were less likely to donate blood. ${ }^{168}$ Although people were allowed to donate blood in the United States, Titmuss theorized donations were crowded out by purchases. ${ }^{169}$ Titmuss believed replacing charity with a market would have deleterious effects on altruism in a

164 Amy Crawford, The Trouble with Organ Banking; Boston Globe (June 1, 2014), https://www.bostonglobe.com/ideas/2014/05/31/thetrouble-with-organ-banking/Gaugdq7GMnEs8mKWISSAyM/story.html [https://perma.cc/E5KC-A3J3]. See also Cynthia B. Cohen, Public Policy and the Sale of Human Organs 12 KenNEDy Inst. OF ETHICS J. 47, 54, available at http://www.hawaii.edu/religion/courses/organsale2.htm [https://perma.cc/SD6R-8NFC] (stating “Titmuss's views about the importance of the gift relationship were brought back into public discussion with respect to the sale of kidneys.").

165 S. M. Rothman \& D. J. Rothman, The Hidden Cost of Organ Sale, 6 AM. J. TrAnsplantation 1524, 1525 (2006), available at http:// www.societyandmedicine.columbia.edu/organs_challenge.shtml [http:// perma.cc/HH9T-PBW2].

166 Iain McLean, The Gift Relationship, PoLicy-NeTwORK.NET, http://www.policy-network.net/publications_download.aspx?ID=6839

[http://perma.cc/U2TQ-NFKY] (last visited Nov. 30, 2015).

167 Sandel, supra note 107, at 123.

168 Id. at 124.

169 Id. 
society. ${ }^{170}$ More recent studies support Titmuss's hypothesis. One such study involved an Israeli daycare where tardy parents were fined. When fines of $\$ 2.50$ were imposed, the number of late pickups increased.171 When the fine was removed, the tardiness persisted. ${ }^{172}$ This implies that placing a price on organs will create a permanent commercial stigma around organs and removal of the price will not necessarily revert social perceptions on organ donations to the way they were pre-commodification.

The impact of commercialization on blood quantity and quality has been well rebutted. At the time of Titmuss's writing, blood screening tests were not prevalent. ${ }^{173}$ Modern blood testing mitigates Titmuss's fear of harvesting the blood of skid row donors infected with hepatitis and other blood borne diseases who are looking for money. ${ }^{174}$ Regarding the effect of money on the quantity of blood, the United States blood supply is obtained almost entirely from altruistic donors. ${ }^{175}$ However, the United States pays plasma providers. ${ }^{176}$ Blood shortages are chronic in the United States, but the United States has a plasma surplus and is a plasma exporter. ${ }^{177}$ Likewise, organ procurement systems that offer compensation, including Spain discussed supra and Iran discussed infra, have better organ procurement rates than other systems. ${ }^{178}$ This trend strongly suggests that financial incentives will increase the organ supply. Turning to the altruism claim, multiple motives go into most actions. Paying donors may send social signals that contradict the charity motivation. ${ }^{179}$ Nevertheless, the key message from

170 Id.

171 Rothman \& Rothman, supra note 165, at 1525.

172 Id.

173 BEARD ET AL., supra note 71, at 98.

174 Id.

175 Id. at 184.

176 Id.

177 Id. at 99.

178 Id.

179 Id. at 98-99. 
the Israeli example is to provide significant compensation or no compensation at all. ${ }^{180}$ Recent research also indicates market incentives may actually increase altruistic behavior. 181

Putting aside all other arguments, the ability to control what happens to one's own body is a matter of freedom. It seems odd for the government to prevent people from making choices that affect only their own body, and this is the fundamental issue involved in the organ market. One may counter this by pointing out that the same principle applies to prostitution and drug use, yet the government prohibits these activities. However, there is a crucial distinction between the aforementioned activities and the ability to sell one's organs. Drug use and prostitution, although they involve only willing participants, are seldom thought to be a social benefit. On the contrary, organ vending has tremendous social value. A life is saved through this consensual transaction, and human suffering is reduced. The vendor stands to benefit from the transaction as well through the receipt of money and the satisfaction of saving a life. If the vendor did not think the transaction was in her best interest, the vendor would not consent to the agreement.

A financial incentive does not diminish the nobility of a deed. The salaried firefighter who risks his life by running into a flaming house to rescue a child is not less valiant than a volunteer firefighter. American soldiers are not less brave because they receive pay. A person need not sacrifice everything and be unrewarded to perform a worthy feat. For this reason, Professor Nicholas Capaldi asserts, "[T]he forprofit sale of an organ or the acceptance of recompense does not of itself reduce organ donation to a mere instrumental use of the body; it thus does not in itself render the donation

180 Id. at 99.

181 Cary Deck \& Erik O. Kimbrough, Do Market Incentives Crowd Out Charitable Giving?, 47 J. SocIO-ECON. 8 (2013), available at http://www.ncbi.nlm.nih.gov/pmc/articles/PMC3857091/./ [http:// perma.cc/T95F-EFAU]. 
less morally praiseworthy." 182 Accordingly, it matters not whether organs are provided to those in need by altruism or a commercial transaction. The organ recipient's life is saved by receiving the organ-not by the method used to procure the organ.

People have the right to engage in all sorts of dangerous activities. The government permits cigarette smoking though smoking has no health benefits; in fact, smoking kills 480,000 Americans each year. ${ }^{183}$ Not only are people allowed use harmful drugs for recreation, people are allowed to engage in dangerous hobbies. BASE jumping may be the most dangerous hobby, as it has a fatality rate of 40 per 100,000 jumps; 184 therefore, BASE jumping is statistically more dangerous than donating a kidney. Aside from BASE jumping, people are free to sky dive, hang glide, mountain climb, and engage in numerous other inherently hazardous activities. People can even earn a living performing some these activities. ${ }^{185}$ If people are allowed to consume cancer sticks and engage in unsafe hobbies, why should competent adults be forbidden from receiving compensation for their organs when the transaction will save a human life?

Americans have a fundamental right to create life. ${ }^{186}$ Procreation can cost nothing but can also be rather pricey as sperm and eggs can be purchased. In Vitro Fertilization and surrogate mothers are very expensive. These, especially surrogacy, present similar ethical issues to an organ market, and a powerful argument can be made that the questions

182 Capaldi, supra note 158, at 142.

183 Health Effects Infographics, CTR. DisEase ConTrol \& PREVENTION (Feb. 27, 2015), http://www.cdc.gov/tobacco/data_statistics/ tables/health/attrdeaths/ [http://perma.cc/45YM-YHDF].

$184 \mathrm{~K}$. Soreide et al., How Dangerous Is BASE Jumping? An Analysis of Adverse Events in 20,850 Jumps from the Kjerag Massif, Norway, 62 J. TRAUMA 1113 (2007), available at http://www.ncbi.nlm.nih.gov/ pubmed/17495709 [http://perma.cc/MPY6-YEWZ].

185 BASE JUmper, INSIDE JOBS, http://www.insidejobs.com/careers/ base-jumper [http://perma.cc/9NPP-X8V8] (last visited Nov. 30, 2015).

186 Skinner v. Oklahoma, 316 U.S. 535 (1942). 
involved in procreation using artificial methods set society on a slope far slipperier than an organ market. Organ transplantation is a widely accepted medical procedure, even by organizations that oppose organ selling. The Vatican, for example, approves of organ transplants. ${ }^{187}$ However, the Vatican categorically opposes "designer babies" because, "[t]he fact that someone would arrogate to himself the right to determine arbitrarily the genetic characteristics of another person represents a grave offense to the dignity of that person as well as to the fundamental equality of all people."188 Yet to exercise the right to procreate, money can be legally used in the United States. Why is spending money to create a life acceptable while using money in a mutually beneficial transaction to preserve a life is deemed illicit?

American law allows the use of deadly force in selfdefense; indeed, self-defense is often regarded as the first law of nature. ${ }^{189}$ The United States also allows the use of deadly force to defend another person. ${ }^{190}$ The life of a viable fetus can be terminated "when it is necessary to preserve the life or health of the mother." 191 In the United States, force or violence can be used to prevent "trespass against property in

187 Address of the Holy Father John Paul II to the $18^{\text {th }}$ International Congress of the Transplantation Society, LIBRERIA EDITRICE VATICANA (Aug. 29, 2000), http://w2.vatican.va/content/john-paul-ii/en/speeches/ 2000/jul-sep/documents/hf_jp-ii_spe_20000829_transplants.html [https:// perma.cc/S8ZV-RVFY]. The Vatican is not categorically opposed to an organ market. See supra note 158.

188 Instruction Dignitas Personae On Certain Bioethical Questions, CONGREGation FOR THE DOCTRINE OF THE FAITH, http:// www.vatican.va/roman_curia/congregations/cfaith/documents/rc_con_cfa ith_doc_20081208_dignitas-personae_en.html [https://perma.cc/2QKGPNC7] (last visited Feb. 4, 2016).

189 Saul Cornell, Natural Rights, Common Law, and the English Right of Self-Defense, 14 INSIGHTS ON LAW AND SoC'Y (2013), available at http://www.americanbar.org/publications/insights_on_law_andsociety/14 /fall-2013/natural-rights--common-law--and-the-english-right-of-selfdefens.html [http://perma.cc/LL4L-Q47E].

190 La. Stat. Ann. § 14:22 (2015).

191 Roe v. Wade, 410 U.S. 113 (1973). 
a person's lawful possession . . ." 192 The law allows selfdefense and defense of property even though these claims may be used to protect a criminal. ${ }^{193}$ Similarly, allowing abortions for the health of the mother can, "become a tool for abortions anytime, for any reason." 194 On this basis, Professor Eugene Volokh asserts people have the right to "medical self-defense" when diagnosed with a terminal condition. ${ }^{195}$ If an individual can legally kill another human being to preserve her life and violently defend property from trespass, surely she should be allowed to enter a consensual commercial transaction to save her life.

\section{MONEY FOR ORGANS}

This section examines the two systems where organ providers are compensated: the black market and the Iranian kidney system. The discussion of each market begins with an overview of their history and circumstances leading to their creation. A discussion of how each market operates follows. By nature, the black market has no formal process, so the discussion generalizes how the market operates based upon accounts from various sources. Next, the outcomes of each market are examined. As the Iranian system has both supporters and detractors, arguments and evidence for each position is weighed. The human organ black market is universally condemned; hence, an analysis its of pros and cons is unnecessary.

192 La. Stat. Ann. § 14:19 (2015).

193 Eugene Volokh, Medical Self-defense, Prohibited Experimental Therapies, and Payment for Organs, 120 HARV. L. REV. 1813, 1817 (2007).

194 Kim Painter, Doctors Say Abortions Do Sometimes Save Women's Lives, USA TODAY (Oct. 22, 2012), http://www.usatoday.com/ story/news/nation/2012/10/19/abortion-mother-life-walsh/1644839/ [http://perma.cc/87RJ-SBX5].

195 Volokh supra note 193, at 1823. 


\section{A. Black Market}

The black market for human organs is a global enterprise. The illegal organ trade was spawned because a demand existed and the supply was artificially constrained. Legislation cannot stop the law of supply and demand. ${ }^{196}$ As one economist notes, "Every time the propensity to exchange is constrained, individuals try to circumvent the constraints in order to obtain what they perceive as the benefits of exchange."197 Regarding the organ market, individuals diagnosed with organ disease have a tremendous demand for functional organs. For the right price, some people are willing to sell their organs. Kidneys are particularly marketable because, as Judge Guido Calabresi says, "We all have too many kidneys; we have two, and we really only need one."198 Although the ingredients for a mutually beneficially exchange are in place, most countries prohibit human organ sales placing a price ceiling of zero on all organs. ${ }^{199}$ Predictably, the price ceiling on human organs has caused a shortage of organs, reduced quality of available organs, and created a black market. ${ }^{200}$

The demand side of the black organ market consists of wealthy, sick patients. ${ }^{201}$ Patients facing certain death or a

196 L D de Castro supra note 132, at 142.

197 Pierre Lemieux, The Underground Economy: Causes, Extent, and Approaches, Montreal Econ. Inst. Research Papers 10 (Nov. 2007), http://www.iedm.org/files/cdr_nov07_en.pdf [http://perma.cc/3RXNF68N].

198 Guido Calabresi, Do We Own Our Bodies?, Faculty SCHOlarshIP SERIES $15 \quad$ (1991), http://digitalcommons.law.yale.edu/cgi/ viewcontent.cgi?article=3066\&context=fss_papers

[http://perma.cc/V4WV-MC29].

199 Aziz, supra note 5, at 68.

200 Fiona M. Scott Morton, The Problems of Price Controls, CATo INST. (2001), http://www.cato.org/publications/commentary/problemsprice-controls [http://perma.cc/TXT3-LAK7].

201 Michael Shafer \& Paige Comstock Cunningham, Medical Exploitation and Black Market Organs: Profiteering and Disparities in Global Medicine, CTR. Bioethics \& Human Dignity (Nov. 4, 2011), 
debilitating life on dialysis are willing to pay well over six figures for a kidney. ${ }^{202}$ These patients often travel to foreign countries and in many cases receive poor quality organs that are not proper matches for their body. ${ }^{203}$ The organs patients receive frequently have HIV and Hepatitis C.204 Likewise, proper medical protocols do not have to be followed during illegal operations, so post operation complications are common. ${ }^{205}$ These complications are difficult to treat when the patient returns to her home country because proper records are not kept on the black market. ${ }^{206}$

Black market buyers often arrange their illegal transplant through organ brokers. Organ brokers come from all walks of life, from organized crime syndicates to medical professionals. ${ }^{207}$ Although the organ provider is usually lured into the transaction by money, physical force and subterfuge are used as well. ${ }^{208}$ Organ brokers target the desperately poor from impoverished countries because poverty is the primary reason why individuals sell their body parts. ${ }^{209}$ Individuals

https://cbhd.org/content/medical-exploitation-and-black-market-organsprofiteering-and-disparities-global-medicine [http://perma.cc/R95CP9WL].

202 Denis Campbell \& Nicola Davison, Illegal Kidney Trade Booms as New Organ is 'Sold Every Hour', The GuARDian (May 27, 2012), http://www.theguardian.com/world/2012/may/27/kidney-trade-illegaloperations-who [http://perma.cc/KLP7-5ZUG].

${ }^{203}$ Kristina Fiore, Physicians Must Treat 'Transplant Tourists', ABC NEWs (Jan. 30, 2010), http://abcnews.go.com/Health/transplant-tourismhidden-risks/story?id=9702948 [http://perma.cc/VS48-6M84].

204 Nancy Scheper-Hughes, Organ Trafficking: A Protected Crime,

The Conversation (Sep. 3, 2013, 1:50 AM), http:// theconversation.com/organ-trafficking-a-protected-crime-16178 [http:// perma.cc/8EKQ-LXUZ].

205 Fiore, supra note 203.

206 Id.

207 Organs for Sale, United NATions Regional InFo. CEnTRE FOR WESTERN EUROPE, http://www.unric.org/en/human-trafficking/27447organs-for-sale [http://perma.cc/Y6NB-9DPG] (last visited Oct. 27, 2015).

208 Shafer \& Comstock Cunningham, supra note 201.

209 Monir Moniruzzaman, "Living Cadavers" in Bangladesh: Bioviolence in the Human Organ Bazaar, 26 MED. Anthropology 
who sell their organs are often completely ignorant as to how the organs operate, and this ignorance enables organ brokers to deceive sellers. ${ }^{210}$

Black market kidney providers typically receive around $\$ 1,000 .^{211}$ In addition to the price of their organs, sellers are promised a myriad of other goodies such as jobs, land, and visas. ${ }^{212}$ Sellers are also told the trip to the transplant site will be jolly. ${ }^{213}$ Tragically, sellers do not have a pleasant experience. They often wait for the transplant in a small, dingy, crowded apartment that functions as a prison. ${ }^{214}$ Attempts to back out of the deal are met by violence. ${ }^{215}$ The surgery is unnecessarily harsh too. Kidneys can be removed with a laparoscope. ${ }^{216}$ Laparoscopic nephrectomy enables the patient to recover quicker than other methods and leaves a smaller scar. 217 However, black market operators are not willing use laparoscopes because the procedure costs a few hundred dollars more than using a scalpel. 218 Sellers are marked with a 20 inch long scar as a result. ${ }^{219}$

Recovery from the operation takes place in the same dank apartment where the seller was held prior to the surgery. 220 Although the recovery from the surgery takes weeks, sellers are so desperate to escape the apartment that they head

QUARTERLY 69, 75 (2012), available at http://news.msu.edu/ media/documents/2012/03/73a832b2-0893-4837-99fb-9ab6d10db302.pdf [http://perma.cc/QZF2-GGML].

210 Id. at $75-76$.

211 Shafer \& Comstock Cunningham, supra note 201.

212 Moniruzzaman, supra note 209, at 77.

213 Id.

214 Id. at 78.

215 Id.

216 Laparoscopic Nephrectomy, THE JAMES BUCHANAN BRADY UROLOGICAL INST., http://urology.jhu.edu/MIS/lap_nephrectomy.php [http://perma.cc/BLW8-432J] (last visited Oct. 27, 2015).

217 Id.

218 Moniruzzaman, supra note 209, at 78.

219 Id. at 78.

220 Id. 
home a few days post operation. ${ }^{221}$ This prevents surgical wounds from healing properly. ${ }^{222}$ Sellers also lack access to healthcare; hence, sellers struggle with health problems post surgery. ${ }^{223}$ Physical issues resulting from the operation prevent sellers from engaging in physical labor; thus, the dire economic prospects that drove sellers to part with their organs are usually exacerbated by the organ sale. ${ }^{224}$

Once their organs are extracted, sellers are routinely not paid in full or denied payment altogether. ${ }^{225}$ Sellers do receive the agreed upon sum sometimes; however, this does not ensure they will keep the money. For example, a Brazilian kidney seller returned home from South Africa three days after the operation with the agreed upon amount in his pocket. ${ }^{226}$ He was robbed soon after landing. ${ }^{227}$ The seller had no recourse because the money was obtained through an illegal transaction. To make matters worse, sellers are socially ostracized. ${ }^{228}$ One Moldovan kidney seller says kidney sellers are treated worse than prostitutes. ${ }^{229}$

Although organ sales are forbidden in virtually every nation, the illegal organ trade is booming. The primary organ purchasing countries include Australia, Canada, Israel, Japan, Oman, Saudi Arabia and the United States. ${ }^{230}$ These illegal organ purchases result in poor health outcomes for both the buyer and seller. ${ }^{231}$ Moreover, coercion is present at

$221 I d$.

$222 I d$.

223 Id. at 78-79.

224 Id. at 79.

225 Organs for Sale, supra note 207.

226 GOODWIN, supra note 139, at 188.

227 Id. at 189.

228 Moniruzzaman, supra note 209, at 78.

229 Shafer \& Comstock Cunningham, supra note 201.

230 Yosuke Shimazono, The State of the International Organ Trade: A Provisional Picture Based on Integration of Available Information, 85 BULlETIN OF THE WORLD HEALTH ORGANIZATION 901-980 (2007), available at http://www.who.int/bulletin/volumes/85/12/06-039370/en/ [http://perma.cc/D86V-M5NU].

231 Id. 
both ends of the transactions. Sellers are generally penniless and ill informed about the risks of the procedure, and buyers are desperate to preserve their lives.

Despite the horrors of the black market and its universal condemnation, prosecutions for illegal organ sales are rare and difficult. ${ }^{232}$ Israeli insurers reimbursed citizens for organ transplants performed anywhere in the world until 2008.233 Still, Israel does not punish organ buyers and sellers because it views these people as victims. ${ }^{234}$ Instead, Israeli law directs its wrath at the brokers and insurance companies that facilitate illegal organ operations. ${ }^{235}$ The United States has only recently convicted the first person under federal law of organ trafficking in 2011.236 The organ broker was released in under three years. 237 Though an immigrant, he was allowed to remain in the United States because his crime was not one of "moral turpitude."238 Perhaps the medical community has reached the same conclusion because it

232 Nancy Scheper-Hughes, Human Traffic: Exposing the Brutal Organ Trade, New InTERnATIONALIST MAGAZINE (May 1, 2014), http://newint.org/features/2014/05/01/organ-trafficking-keynote/ [http://perma.cc/33LZ-2WZH].

233 Dimitri Linde, Israel, a Leader in Transplant Tourism, Finds a Formula for Increasing Domestic Donation, TABLET (Apr. 10, 2014), http://tabletmag.com/jewish-news-and-politics/164976/israel-organdonation [http://perma.cc/H48X-5HGW].

234 Asif Efrat, Combating the Kidney Commerce: Civil Society Against Organ Trafficking in Pakistan and Israel, 53 BRIT. J. CRIMINOLOGY 764, 777 (Apr. 26, 2013), available at http://bjc.oxfordjournals.org/content/early/2013/04/22/bjc.azt025.full.pdf [http://perma.cc/QS55-7AJN].

235 Id.

236 Brooklyn Man Pleads Guilty in First Ever Federal Conviction for Brokering Illegal Kidney Transplants for Profit, FBI (Oct. 27, 2011), http://www.fbi.gov/newark/press-releases/2011/brooklyn-man-pleadsguilty-in-first-ever-federal-conviction-for-brokering-illegal-kidneytransplants-for-profit [http://perma.cc/ADT5-4QHK].

237 David Glovin, Organ Broker Skirts Expulsion After 'Victimless' Claim, BloomberG (Dec. 23, 2014, 7:39 PM), http:// www.bloomberg.com/news/articles/2014-12-24/organ-broker-skirtsexpulsion-after-victimless-claim [http://perma.cc/5DSB-JL4B].

238 Id. 
provides care to patients who illegally buy organs. ${ }^{239}$ This encourages people to enter the black market while it penalizes those who follow the law and wait in the organ queue. Black market organ buyers and sellers do so because they have nowhere else to turn. ${ }^{240}$ Punishing such people is tough.

\section{B. Iranian Kidney System}

Iran's organ transplant system began as part of Eurotransplant, ${ }^{241}$ a central registry that stores data from several European countries and uses a compatibility matching system to allocate organs. ${ }^{242}$ However, the Iranian Revolution severed the country's relationship with Eurotransplant. ${ }^{243}$ The Iran-Iraq War began soon after the Revolution. These circumstances left Iran isolated and economically impaired; hence, Iran struggled to procure dialysis equipment. ${ }^{24}$ From 1980 through 1985, dialysis patients in need of transplants had to travel abroad for the transplant, and living related donors provided most of the kidneys. ${ }^{245}$

The Iranian government funded the expensive surgery, and the increasing number of patients on the kidney transplant waiting list caused the Iranian government to establish kidney transplant centers in 1985.246 The capacity to perform transplants inside Iran was only half the battle.

239 Fiore, supra note 203.

240 Woan, supra note 122 , at 428.

241 FRY-REVERE, supra note 153, at 50.

242 Welcome on the Homepage of ETRL, EUROTRANSPLANT REFERENCE LABORATORY, http://etrl.eurotransplant.org/cms/index.php [http://perma.cc/R643-JXR3] (last visited Nov. 6, 2015).

243 FRY-REVERE, supra note 153, at 50.

244 Ali Nobakht Haghighi \& Nasrollah Ghahramani, Living Unrelated Kidney Donor Transplantation in Iran, NATURe ClinICAL PRACTICE NEPHROLOGY (2006), http://www.nature.com/nrneph/ journal/v2/n12/full/ncpneph0364.html [http://perma.cc/6ZJW-W2MQ].

245 Ghods and Savaj, supra note 9, at 1137.

246 Id. 
As is the case in every nation, the number of Iranians in need of a kidney exceeded the supply of living related donors. ${ }^{247} \mathrm{~A}$ cadaver organ system was impractical in Iran because Iran lacked the infrastructure to preserve and transport organs. ${ }^{248}$ Iranians also have a religious taboo against removing organs from the dead. ${ }^{249}$ Thus, Iran created "a government-funded, regulated, and -compensated living-unrelated donor renal transplantation program" in $1988 .{ }^{250}$

Creating a kidney market was not Iran's goal. The exchanges between kidney providers and recipients occurred naturally. Iranian medical personnel simply overlooked the transactions because they did not want their patients to die.251 Wanting the best for their patients, the Iranian medical community hoped to regulate kidney exchanges. ${ }^{252}$ Medical professionals were interested in screening donors and contract enforcement. ${ }^{253}$ Individuals seeking to purchase a kidney sought to prevent would-be donors from taking a deposit then absconding from the contract as well as paying to screen individuals who fraudulently stated they were healthy enough to donate. ${ }^{254}$ Interestingly, recipients believed the donors deserved higher levels of compensation than recipients were able to provide and wanted to provide donors with health insurance. ${ }^{255}$

Although Iran has a compensated donor program, physicians explain to patients the advantages of using a living related kidney donor over an unrelated donor. ${ }^{256}$ If the patient has no living related donor, or decides against using a living related donor, the patient is referred to a non-

247 Id.

248 FRY-REVERE, supra note 153, at 50.

249 Id. at 134.

250 Ghods \& Savaj, supra note 9, at 1137.

251 FRY-REVERE, supra note 153, at 50.

252 Id.

253 Id.

254 Id.

$255 I d$. at $50-51$.

256 Ghods \& Savaj, supra note 9, at 1137. 
governmental organization, ${ }^{257}$ called an Anjoman, also referred to as Dialysis and Transplant Patients Associations (DATPA). Anjomans oversee Iran's compensated living unrelated kidney donor program and help locate matching kidneys for patients. ${ }^{258}$ Anjomans serve the same function as brokers do on the black market ${ }^{259}$ but are much more than benevolent kidney matchmakers. ${ }^{260}$ Anjomans seem to genuinely care about their functions; accordingly, they assist patients medically and socially. ${ }^{261}$

Anjomans attempt to make the donor's experience as positive as possible because a donor that is well taken care of will encourage future donations. ${ }^{262}$ To accomplish this goal, potential donors are screened by Anjoman staff. Potential donors are allowed to part with their kidney only if the Anjoman believes participating in the transplant can benefit the donor. ${ }^{263}$ If the Anjoman thinks the operation will retrogress a seller, the Anjoman forbids the individual from donating her kidney. ${ }^{264}$ If a kidney provider is approved, Anjomans ensure the donor is compensated. ${ }^{265}$ The desire to help displayed by Anjomans is likely a consequence of their volunteer workforce composed of people who have participated in the transplant process. ${ }^{266}$

The Iranian Ministry of Health began compensating donors in 1987-88, and the Iranian parliament formally approved a payment of one million tomans in 1995 with the goal of eliminating price negotiations during kidney sales. ${ }^{267}$ However, inflation eroded the value of the toman, and the

257 Id.

258 FRY-REVERE, supra note 153, at 51.

259 Ghods \& Savaj, supra note 9, at 1137.

260 FRY-REVERE, supra note 153, at 51.

261 Id.

262 Id.

263 Id. at 157.

264 Id. at 140.

265 Id. at 100.

266 Haghighi \& Ghahramani, supra note 244.

267 Id. at 83. 
government did not increase the price. ${ }^{268}$ Consequently, prices are now negotiated. ${ }^{269}$ Kidney donors in 2009 received one million toman from the government plus an additional four to five million toman from the recipient on average. ${ }^{270}$ Inflation makes comparing Iranian and American currencies difficult, ${ }^{271}$ but the average Iranian individual income was approximately $\$ 3,000$ in 2009.272 The average price for a kidney during this period was approximately $\$ 5,000.273$ When the recipient is poor and unable to afford a kidney, charities compensate the kidney provider. ${ }^{274}$

Aside from donor compensation, other aspects of the transplant process are covered too. Recipients of kidneys can purchase immunosuppressive drugs for a low price because the drugs are subsidized. ${ }^{275}$ Charitable organizations provide immunosuppressive drugs for indigent transplant recipients. ${ }^{276}$ Iranian kidney donors also receive one year of health care from the government, ${ }^{277}$ and in some regions of Iran, health insurance for life. 278 If male, donors are exempted from Iran's mandatory military service. ${ }^{279}$ Kidney recipients commonly give the kidney seller more than the negotiated price. Additional compensation can be monetary but may also be in the form of food, clothing, or other goods. ${ }^{280}$ In nearly half of kidney transactions between living unrelated donors, the provider and recipient develop a mutual friendship. ${ }^{281}$

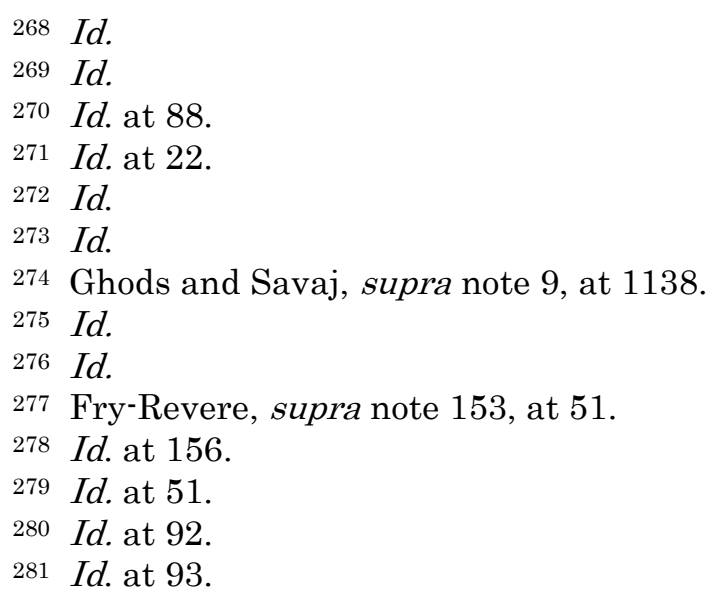


Organ transplants in Iran, despite appearances, are not commercial transactions. 282 Transplants are performed in government run hospitals at the government's expense. ${ }^{283}$ Any valuable consideration exchanged between the organ provider and recipient is regarded as a token of appreciation. ${ }^{284}$ Iranian law reasons a kidney saves the life of the recipient, and life is priceless. 285 No amount of compensation can repay the donor for her sacrifice therefore, emoluments given to the donor are signs of gratitude. ${ }^{286}$ Hence, organ transactions are mutual gifting rather than commercial sales under Iranian law. ${ }^{287}$ Under Sharia Law, agreements to exchange gifts are legally enforceable. ${ }^{288}$

The gratuitous nature of the transaction means Iranians view those who sell their kidneys as "donors."289 To understand this view of the Iranian kidney transplant system, the sociological conditions at the time of the system's establishment must be put in context. ${ }^{290}$ Years of ruinous war with Iraq had generated a spirit of sacrifice inside Iran. ${ }^{291}$ This inspired the Iranian living unrelated donor program where donors are compensated but still regarded as altruistic. ${ }^{292}$ Iranian Ayatollah Mohaghegh Damads asserts, "[t]he Qu'ran looks favorably on those who help themselves

282 B. Larijani et al., Ethical and Legal Aspects of Organ Transplantation in Iran, 36 TRANSPLANTATION PROCEEDINGS 1241, 1242 (2004), available at http://ac.els-cdn.com/S0041134504005974/1-s2.0S0041134504005974-main.pdf?_tid=18e6a234-7834-11e5-bb1400000aacb35e\&acdnat=1445460265_54a892f6601ca925fbf98821649a10 $3 \mathrm{~d}$,. 283 Id.

284 Haghighi \& Ghahramani, supra note 244.

285 FRY-REVERE, supra note 153, at 99.

286 Id.

287 Id. at 100.

288 Id at 101.

289 Haghighi \& Ghahramani, supra note 244.

290 Id.

291 Id.

292 Id. 
by helping others."293 Thus, personal reward does not diminish the donor's sacrifice nor the good done by providing a kidney. The kidney provider saves a life, and the Qu'ran states, "if any saves a life it is as if he saves the lives of all mankind."294

Although these are the basics of the Iranian system, Anjomans operate slightly different in each region. ${ }^{295}$ In Shiraz, using a compensated kidney donor is discouraged.296 Donors and recipients are prohibited from "commercializing" the transaction beyond the government-guaranteed one million tomans. ${ }^{297}$ Anjoman personnel in Shiraz deny knowledge of recipients providing donors with additional compensation, and no amount agreed upon would be legally binding in Shiraz. ${ }^{298}$ Kermanshah's Anjoman treat patients less hospitably than Anjomans in other regions; nevertheless, Kermanshah's Anjoman manages to protect the interests of donors. ${ }^{299}$

Iranians must donate in their home province. ${ }^{300}$ Theoretically, an Iranian could establish residence in another province if he had relatives there. The cost of travel and medical care related to the surgery, as well as the ability to access nonmedical benefits provided by the Anjoman, render travel infeasible for most Iranians. ${ }^{301}$ Living unrelated donations are also restricted to individuals of the same nationality, and non-Iranian citizens must pay for their own surgery. ${ }^{302}$

\footnotetext{
293 FRY-REVERE, supra note 153, at 100.

294 e.x. Surat I-maidah 5:32.

295 FRY-REVERE, supra note 153, at 112.

$296 \mathrm{Id}$. at 57.

$297 \mathrm{Id}$. at 59.

298 Id.

299 Id. at 187.

$300 \mathrm{Id}$. at 60 .

301 Id.

302 Id. at 19.
} 


\section{ANALYSIS AND CRITIQUE OF IRAN'S KIDNEY SYSTEM}

Following this model, Iran has not had a kidney waiting list since 1999. ${ }^{303}$ No other country has been able to eliminate its kidney waiting list. ${ }^{304}$ In fact, Iran's kidney program has produced a surplus of willing kidney providers. ${ }^{305}$ Although having a surplus of willing donors may appear to be a good situation, the number of Iranians willing to part with their kidneys gives opponents of organ sales reason to question the Iranian system.

Critics of the Iranian system, and organ markets in general, note compensated Iranian donors are usually poor, and donors are compelled by their social condition to sell their kidneys. 306 A study of compensated Iranian kidney donors found $6 \%$ of donors were illiterate, $24.4 \%$ had only an elementary education, and $63.3 \%$ had high school educations, while only $6.3 \%$ had attended college. 307 The same study found $84 \%$ kidney providers were poor and $16 \%$ were middle class. ${ }^{308}$ Wealthy Iranians do not part with their kidneys for compensation. There are also reports of the screening process failing to catch financially desperate people. ${ }^{309}$ In the six months prior to the compensated kidney donation, the most

303 Ghods \& Savaj, supra note 9, at 1137.

304 Benjamin E. Hippen, Organ Sales and Moral Travails: Lessons from the Living Kidney Vendor Program in Iran, 614 CATO POL'Y ANALYSIS 1, 4 (Mar. 20, 2008), available at http://www.cato.org/sites/ cato.org/files/pubs/pdf/pa-614.pdf [http://perma.cc/8PVF-EUHL].

305 Anne Griffin, Kidneys on Demand, 334 BRIT. M. J. 502, 504 (Mar. 10, 2007), available at http://www.ncbi.nlm.nih.gov/pmc/articles/ PMC1819484/pdf/bmj-334-7592-feat-00502.pdf [http://perma.cc/9WFE$8 \mathrm{ALR}]$.

306 Francis L. Delmonico, The Alternative Iranian Model of Living Renal Transplantation, 82 KIDNEY INT'L. 625 (2012).

307 Ghods \& Savaj, supra note 9, at 1140.

308 Id.

309 B. Broumand, Living Donors: The Iran Experience, 12 NEPHROLOGY DiALYSIS TRANSPLANTATION 1830, 1831 (1997), a vailable at http:// ndt.oxfordjournals.org/content/12/9/1830.full.pdf [https://perma.cc/ F9HD-PK5F]. 
common life events experienced by donors were increased life expenses, low income, and household duties. ${ }^{310}$ These events were usually triggered by financial problems, losing one's job, and a family member's death. 311

As a majority of compensated donors are poor and not well educated, concerns have been raised about the pretransplant screening process. ${ }^{312}$ There are reports of kidney providers being rushed through the donation process allowing providers with diseases such as HIV and tuberculosis to donate their kidneys. ${ }^{313}$ Health is a concern after the operation as well because compensated donors showed poor health three months after the surgery. ${ }^{314}$ Most compensated donors are not fully aware of the complications associated with living kidney donation and do not partake in follow up healthcare. ${ }^{315}$ Psychological healthcare is an issue for compensated donors as $51 \%$ of compensated donors hated the person who received their kidney. 316 Three-quarters of kidney providers did not achieve their financial goals after the compensated donation, ${ }^{317}$ so depression may be a problem among compensated donors. Compensated kidney donors also report being socially ostracized. ${ }^{318}$ Additionally, the compensated living unrelated donor program is blamed for

310 Ali-Akbar Nejatisafa et al., Quality of Life and Life Events of Living Unrelated Kidney Donors in Iran: A Multicenter Study, 86 TRANSPLANTATION 937, 938 (2008), available at https:// www.researchgate.net/publication/23317754_Quality_of_Life_and_Life_ Events_of_Living_Unrelated_Kidney_Donors_in_Iran_A_Multicenter_St udy [https://perma.cc/5BZ8-X9HW?type=source.]

311 Id.

312 E.J. Gordon \& J.S. Gill, Where There Is Smoke There Is Fire: The Iranian System of Paid Donation, 13 AM. J. TRANSPLANT 3063 (2013).

313 Broumand, supra note 309, at 1831.

314 Nejatisafa et al., supra note 310, at 940.

315 Gordon \& Gill, supra note 312, at 3064.

316 Javaad Zargooshi, Iranian Kidney Donors: Motivations and Relations with Recipients, 165 J. UROLOGY 386-392 (2001).

317 Id.

318 FRY-REVERE, supra note 153, at 88. 
impeding the development of Iran's cadaver donation program..$^{319}$

Most studies suggest the majority of compensated donors are poor, but some report the preponderance of compensated donors are middle class. 320 Regarding concerns about exploitation of the Iranian poor, it is important to note that the majority of Iranian kidney purchasers are poor. ${ }^{321}$ Iranians would rather compensate a live donor and receive a kidney quickly than wait to accept a free kidney from a cadaver.$^{322}$ If the poor are exploited by the Iranian kidney market, Afghan refugees in Iran are prime candidates for exploitation as these Afghans are among the Earth's most impoverished people. ${ }^{323}$ There are no known cases of Afghans participating in compensated donation of their kidneys with non-Afghans. ${ }^{324}$ Interestingly, approximately $80 \%$ of Afghans who receive kidney transplants in Iran use paid living unrelated donors. ${ }^{325}$ For this reason, Iran's kidney system is credited with providing equal access to kidney care "regardless of gender and economic circumstances." 326

Aside from eliminating the kidney waiting list, Iran's system has greatly reduced the presence of coercion in kidney transactions. ${ }^{327}$ The regulated infrastructure prevents the horrors of the black market. ${ }^{328}$ Brokers have incentives to deceive both the patient and organ provider because a

319 Gordon \& Gill, supra note 312, at 3064.

320 Fry-Revere, What Can Iran Teach US About the Kidney Shortage?, supra note 7.

${ }^{321}$ Ghods \& Savaj, supra note 9, at 1140.

322 FRY-REVERE, supra note 153, at 132-33.

323 Ghods \& Savaj, supra, note 9, at 1141.

324 Id.

325 Id.

326 Behzad Einollahi et al., Deceased-donor Kidney Transplantation in Iran; Trends, Barriers, and Opportunities, 4 J. MED. ETHICs 70 (2007) available at http://ijme.in/index.php/ijme/article/view/536/1396 [https:// perma.cc/Z3Q2-8KK8].

327 Id.

328 Haghighi \& Ghahraman, supra note 244. 
broker's payment hinges on the deal going through. ${ }^{329}$ Plus, buyers and sellers have no legal recourse against organ brokers. Brokers are not necessary in Iran because compensated donors choose to present themselves for the kidney transaction. ${ }^{330}$ Iran's kidney system is governed by nonprofit entities that are staffed by volunteers, so these institutions have no incentive to disenfranchise donors or recipients. ${ }^{331}$ Therefore, providing a legal framework to compensate kidney donors has prevented the exploitation associated with sales on the black market. ${ }^{332}$

Financial coercion is often cited as the reason for preventing organ sales; nevertheless, there are other forms of coercion. Family pressure can be even more daunting than financial pressure, and the Iranian kidney system prevents familial coercion to donate an organ. ${ }^{333}$ Iranian males must serve in the military. ${ }^{334}$ However, men can be exempted for medical reasons, to care for elderly relatives, and to pursue an education. ${ }^{335}$ The Iranian parliament considered a proposal allowing men to purchase an exemption, but this proposal was shutdown as discriminatory against the indigent.336 Donating a kidney enables men to avoid conscription; 337 thus, the ability to choose whether to donate a kidney reduces the government's coercive power over Iranian men.

Although the health of compensated donors was worse three months after the donation than prior to the donation, the health of Iranian donors made a full recovery by the end

329 Hippen, supra note 304, at 4.

$330 \mathrm{Id}$. at 7.

331 Id. at 4.

332 Haghighi \& Ghahramani, supra note 244.

333 Larijani, supra note 282, at 1242.

334 Iran's New Military Policy Could Boost Birthrates, AL-Monitor (Oct. 12, 2014), http://www.al-monitor.com/pulse/originals/2014/10/iranmilitary-conscription-service.html\# [https://perma.cc/4SSH-KGBC].

$335 \mathrm{Id}$.

336 Id.

337 FRY-REVERE, supra note 153 at 51. 
of the year. ${ }^{338}$ The criticism leveled at Iran for not following kidney providers post operation is a consequence of limited resources. 339 Compensated donors often live far from the transplant center and are unable or uninterested in journeying back to the medical facility for a checkup. ${ }^{340}$ Of the donors that were followed, a majority of compensated donors were satisfied with the transaction and suffered no serious health problems. ${ }^{341}$ The social stigma mentioned by some kidney providers is likely an outcome of compensated donors being perceived as unable to earn money through more conventional methods. ${ }^{342}$

The account cited supra stating compensated donors are displeased with having donated their kidney was from a sample of 100 Iranians taken over 20 years ago. ${ }^{343}$ Moreover, the study was performed in one province, Kermanshah. ${ }^{344}$ Dr. Sigrid Fry-Revere's 2008-2009 study examined multiple regions, and she had the lowest regard for the system in Kermanshah. ${ }^{345}$ Accounts that blame Iran's living donor program for the country's low cadaver donor rate are similarly flawed as each region of the country acts differently. Shiraz has been acknowledged by critics of the Iranian kidney system as "exemplary" in procuring and performing cadaver transplants. ${ }^{346}$ Since Iran legalized

338 Nejatisafa et al., supra note 310 , at 940.

339 Ghods, supra note 10, at 226.

340 Id.

341 Heidary Rouchi et al., Compensated Living Kidney Donation in Iran: Donor's Attitude and Short-term Follow-up, 3 IRANIAN J. OF KIDNEY DISEASES 34, 34-39 (2009), available at http:// applications.emro.who.int/imemrf/ijkd_2009_3_1_34.pdf.

342 Fry-Revere, supra note 153, at 89.

343 Zargooshi supra note 316.

344 Id.

345 Id. at 178.

346 Delmonico supra note 306, at 626. 
cadaver donation in 2000, Iran has proceeded with cadaver donation much like other nations. ${ }^{347}$

Iran's kidney system is not perfect. No agency monitors the long-term outcome of kidney donations in Iran, ${ }^{348}$ so conclusions about the system are made with limited information. Likewise, physical and mental health services should be provided to kidney providers long after the transaction. ${ }^{349}$ The Iranian system has not completely eliminated the black market either. ${ }^{350}$ The government payment system has not kept pace with the cost of living, and this has caused would-be recipients and donors to negotiate a price-the very thing the government payment was supposed to prevent. ${ }^{351}$ Nevertheless, Iran has eliminated its kidney waiting list. A feat that has yet to be replicated.

Iran is not a free country. 352 The Iranian government is a tyranny. ${ }^{353}$ Iran is not an adherent of laissez-faire economics. On the contrary, Iran's economy is one of the world's most restricted, ranked 171 out of $178 .{ }^{354}$ This aversion to freedom has not prevented Iran from using market based incentives as a solution to the kidney shortage. Other countries should take note.

347 Mitra Mahdavi-Mazdeh et al., Renal Replacement Therapy in Iran, 4 UROL. J. 66, 67 (2007), available at http://www.sid.ir/En/ VEWSSID/J_pdf/83020070203.pdf. [http://perma.cc/KWF6-2KYH].

348 Bobak Zonnoor, How to Sell Your Kidney: A Brief Overview of the Iranian Model for Kidney Transplantation, IN-TRAINING (Mar. 21, 2014), in-training.org/sell-kidney-brief-overview-iranian-model-kidneytransplantation-5682 [http://perma.cc/4BCC-8N6M].

349 Nejatisafa et al., supra note 310 , at 940.

350 Zonnoor, supra note 348.

351 FRY-REVERE, supra note 153, at 83.

352 Iran, FREEDOM House (2015), https://freedomhouse.org/report/ freedom-world/2015/iran\#.VQiww47F8uc [https://perma.cc/WE8UVN8D].

353 Behrooz Behubudi, Iran: 35 Years of Religious Tyranny, THE MIDDLE EAST http://www.themiddleeastmagazine.com/wp-mideastmaglive/2014/02/iran-35-years-of-religious-tyranny/ [http://perma.cc/GK2YBUZW] (last visited Jan. 2, 2016).

354 Country Rankings, 2016 Index OF ECONOMIC FREEDOM, http://www.heritage.org/index/ranking [https://perma.cc/HM6E-EY66]. 


\section{AN ORGAN MARKET IN THE UNITED STATES}

This section sets forth two organ markets. One is a market for live organs, and the other is a cadaver market for all organs. In the live market, kidneys are the focus. This is because kidney extraction is relatively simple compared to other organ extractions but also because kidneys are the organ most in demand. The cadaver market will be for all organs because there is less risk of harm when extracting organs from cadavers.

\section{A. Live Organ Market}

There is only one system where compensating organ providers is legal. Accordingly, the best organ purchasing mechanism system is unknown. This does not mean implementing a market for organs is a step into totally foreign terrain. On the contrary, the market for organs could operate just like the current United States' transplant system. Organ Procurement Organizations operate very similar to Iranian Anjomans. ${ }^{355}$ UNOS can act as a monopsony, and a monopsony is the only ethically plausible system for an organ market. ${ }^{356}$ Turning UNOS into a monopsony allows UNOS to distribute organs just as it currently does. The method used to pair organ providers and recipients is unaffected by whether the organ is purchased or donated. The same holds true for the medical process. Transplant teams will not alter their technique based upon the reason the organ has become available.

Most aspects of the transplant system will remain the same once payment for organs is allowed, but determining the price and the best method of distributing compensation to organ providers is a task that will require study. Experimentation with various aspects of the market should

355 Hippen, supra note 304, at 9.

356 BEARD ET AL., supra note 71, at 194. 
be allowed to occur. ${ }^{357}$ A federalist approach to the organ market is well suited for such experimentation. As Justice Louis Brandeis noted, "It is one of the happy incidents of the federal system that a single courageous State may, if its citizens choose, serve as a laboratory; and try novel social and economic experiments without risk to the rest of the country." 358 Allowing states to design their own systems enables the states to account for their own unique populations, cultures, and geographies. ${ }^{359}$ Plus, permitting diverse compensation systems provides empirical data on whether compensation can increase the organ supply, and if so, what is the best method of providing compensation to organ providers. ${ }^{360}$

Although a federalist approach is suggested, the federal government should set certain guidelines for states. The organs will be purchased through a federal monopsony, so the federal government should set the price for organs. The federal amount will serve as the price floor, but states may choose to provide additional compensation to organ providers. Such compensation can be in the form of tax breaks, vouchers, employment preferences, or other means the state deems legitimate.

Calculating organ prices is difficult because organ sales are prohibited virtually everywhere. Nevertheless, various methods have been proposed to measure the value of organs. One way to value organs is using tort judgments. Tort awards are not appropriate for accessing the price of organs during a sale because the purpose of tort is "making the plaintiff

357 Hippen, supra note 304, at 11.

358 New State Ice Co. v. Liebmann, 285 U.S. 262, 311 (1932). (Brandeis, J., dissenting).

359 Michele Goodwin, Rethinking Federal Organ Transplantation Policy: Incentives Best Implemented by State Governments, in WHEN ALtruism Isn'T ENOUgh: THE CASE FOR COMPENSATING KidNEY DONORS 111, 121 (Sally Satel ed., 2008), available at http://www.aei.org/wpcontent/uploads/2014/07/-when-altruism-isnt-enough_161836373082.pdf [http://perma.cc/RQ38-VAWB].

360 Id. 
whole." ${ }^{61}$ In organ sales, the recipient is being made whole, not the seller. Hence, tort awards are not a proper fit to gauge the market price of a kidney. The other means of assessing an organ price is to use information from the available markets. On the black market, organ prices vary widely. 362 This is due in part to transactions occurring around the globe and in many currencies. In United States dollars, kidneys have been sold for as little as $\$ 650^{363}$ and bought for as much as $\$ 300,000.364$

Iran probably provides the best measure of kidney price. The average kidney "price" in Iran is approximately twice the mean Iranian income when the government, Anjoman, and recipient payments are summed. ${ }^{365}$ In 2013 , the United States average per capita income was $\$ 28,155.366$ Accordingly, valuing a kidney at roughly $\$ 50,000$ seems like a reasonable rate of compensation for an American kidney. This does not mean all kidneys must be sold for the same price though as certain kidneys may be more desirable than others. ${ }^{367}$ A formula that considers factors such as the

361 Jill Wieber Lens, Honest Confusion: The Purpose of Compensatory Damages in Tort and Fraudulent Misrepresentation, 59 KAN. L. REV. 231, 235 (2010), available at https://law.ku.edu/ sites/law.drupal.ku.edu/files/docs/law_review/v59/02-Lens_Final.pdf [https://perma.cc/BS2K-K28M].

362 Organ Trafficking Prices and Kidney Transplant Sales, HAVOCSCOPE, http://www.havocscope.com/black-market-prices/organskidneys/ [https://perma.cc/BC46-6J8J] (last visited Feb. 4, 2016).

363 Gitonga Njeru, Kenya: Sex-trafficked Women and Girls Also Vulnerable to Organ Trafficking, WOMEN NEWs NETWORK (Sep. 13, 2011), http://womennewsnetwork.net/2011/09/13/kenya-women-girls-organtraffickin/ [http://perma.cc/Y4FH-2V6L] (last visited Oct. 22, 2015).

364 Jason Gale \& Quah Chin Chin, Singapore Tycoon to Be Jailed in

Cash-for-Kidney Case, BlOOMBERG (Sep. 3, 2008) http://www.bloomberg.com/apps/news?pid=newsarchive\&sid=a0vvBzm2 UVzg\&refer=asia [http://perma.cc/Q683-TVYA].

365 FRY-REVERE, supra note 153, at 220.

366 State \& County QuickFacts, U.S. CEnsus Bureau, http://quickfacts.census.gov/qfd/states/00000.html (last updated Sept. 30, 2015) [http://perma.cc/U27C-FBM3].

367 BEARD ET AL., supra note 71, at 196. 
seller's age, rarity of blood type, and family medical history would be fair to include in kidney valuation. Thus, the price floor for kidneys should be set at a minimum of $\$ 50,000$.

Distributing money to sellers presents challenges too. There are two issues to consider in disbursing the funds. One is whether to provide a lump sum or periodic payments. The other issue is whether to provide the payment immediately or defer the payment. States will have the option to choose how to allot the funds and can select one or more methods. Below, the four ways to approach the two issues are presented with their potential pros and cons.

1.) Immediate lump sum payment: Providing sellers with the full price of their kidney upfront probably provides the most powerful incentive for an individual to sell her kidney. The lump sum option enables sellers to improve their lives substantially and quickly. Putting $\$ 50,000$ towards paying off debt, starting a business, or other use can have a sudden and dramatic positive impact on the seller's life. Contrarily, placing all of the money in the seller's hands at one time means there is a chance the money can disappear immediately. People who suddenly receive large sums of money at once, such as Lottery winners, often squander it. 368 Organ vendors going into financial ruin soon after the operation is bad for the individual, and the purpose of legalizing the market is to improve the lives of both the organ recipient and provider. Plus, news of organ sellers worsening their lives by vending their organs will discourage future sales. The purpose of the market is to increase the supply of organs; hence, it is imperative that sellers have positive experiences.

2.) Immediate periodic payments: Providing sellers with small periodic payments immediately after selling should minimize the odds of whimsical spending. This reduces the odds of sellers ending up in a worse financial position than

368 The Associated Press, 'I Had to Adapt to This New Life:' As Powerball Drawing Nears, Former Lottery Winners Say Hitting the Jackpot Comes at a Price, N.Y DAILY NEWS (Nov. 28, 2012) http://www.nydailynews.com/news/national/mega-lottery-winnerssound-advice-article-1.1209336?localLinksEnabled=false [http:// perma.cc/XGA4-6ZTS]. 
they were before the sale. It also provides a steady stream of income, even if the payments are only a few hundred dollars per month. Stretching the payments can make the money last longer as the amount will collect interest. The downside of periodic payments is the incentive may not be as powerful as the lump sum payment because the periodic payments do not have the instant effect that the lump sum does. Accordingly, periodic payments may not result in as many sales as lump sum payments, at least in the short run.

3.) Deferred lump sum payment: Deferring the payment virtually eliminates the possibility of duress playing a role in the transaction because the seller will receive no immediate benefit from the sale. Interest is also accruing on the payment while the sum remains in the bank. However, as the interval between the organ extraction and the payment increases, the number of people interested in selling their organs may decrease. The pain and risks of the operation are instantaneous, so deferring payment may lead people to assume the risk is not worth the reward. On the other hand, people who choose to undergo the procedure for a delayed benefit are more likely to have a plan for how they will use the proceeds of the sale. Presumably, such individuals are more likely to use the money prudently than they are to spend it on frolics.

4.) Deferred periodic payments: Deferred periodic payments operate very much like a pension and could feasibly be fused with a retirement package. The danger of placing payments for an organ in a retirement fund is the retirement fund could go broke. It would be tragic if organ providers exchanged their organs for a sum of money they will never see. For this reason, deferred periodic payments may not be attractive to potential sellers. Nevertheless, this option may be appealing to some. Knowing a sum of money is guaranteed regardless of how the stock market or their retirement fund performs could be attractive. Plus, the sum is generating interest payments during the deferment.

Regardless of how the states choose to distribute the money, the federal government should ensure states meet certain criteria. The purpose of these criteria is to protect the financial and physical wellbeing of vendors. Six safeguards are listed below. 
1.) The live organ market should be limited to kidneys initially. This is because kidney extraction is the safest of the organ extractions, ${ }^{369}$ and this fact will presumably make a kidney market more palatable to opponents of organ sales. Kidneys are also the organs most in demand. Eliminating the kidney shortage erases roughly 100,000 names from the organ queue. If the kidney market proves successful, then expanding the market to include other organs will make sense.

2.) Organ providers post operative living expenses should be covered. Although sellers are compensated for the transaction, providing an organ for transplant currently cost donors an average of $\$ 5,000.370$ This cost should be made clear to sellers, so they know to subtract $\$ 5,000$ from the purchase price. Health insurers nor the government need necessarily be responsible for the post operative care. Charities will likely assist organ providers, both sellers and donors, once doing so is legal. ${ }^{371}$ Currently, the ALODF attempts to allay the burden on donors by providing financial support. ${ }^{372}$ ALODF is operating in a legal gray area. If the law clearly allowed organ providers to receive "valuable consideration," one assumes more assistance would be available to donors.

3.) Health insurance should be provided to all organ providers. The organ provider is undergoing a risk for the

369 Katrina A. Bramstedt, Living Liver Donor Mortality: Where Do We Stand?, 101 Am. J. Gastroenterology 1, 4 (2006), available at http://www.clevelandclinic.org/bioethics/documents/LiverDonorMortalit y.pdf [http://perma.cc/H72D-VC4T].

370 Am. Transplant Found. \& Lisa Shankar, Understanding the Barriers to Living Donation, AM. TRANSPlant Found. http://www.americantransplantfoundation.org/programs/ mentorshipprogram-2/mentor/living-donor-connectors/understanding-the-barriersto-living-donation/ [http://perma.cc/YWS3-7JFW] (last visited Oct. 22, 2015).

371 Hippen, supra note 304, at 9.

372 Mission, AM. LIVING ORGAN DONOR FUnd, http:// www.helplivingdonorssavelives.org/about-us/our-mission/ [http:// perma.cc/CG47-42U3] (last visited Oct. 22, 2015). 
purpose of saving a life. Protecting the organ provider's health is a logical way to compensate the provider for the risk. Health insurance should be provided to donors as well as sellers. Congressional republicans continue attempting to repeal the ACA, ${ }^{373}$ but regardless of whether they ever succeed, healthcare can be offered to organ providers through government exchanges, Medicaid, Medicare, or a fully refundable health insurance tax credit. Even the libertarian Cato Institute is open to providing organ sellers and donors with healthcare. ${ }^{374}$

4.) Minimum organ seller-screening criteria should be established. A goal of legalizing the organ market is to reduce exploitation of the poor and incompetent. Setting forth a minimum waiting period prior to selling a kidney reduces the likelihood of a duress-induced sale. Similarly, psychological testing should occur to ensure the seller is competent and is aware of the risks of the procedure.

5.) Exempt kidneys and all organs, as well the proceeds of organ sales, from seizure. As preventing exploitation of sellers is a motivation for legalizing organ sales, prohibiting creditors from establishing claims to the organs of a debtor is imperative. Similarly, creditors should be barred from claims against money received from organ sales. Organ sellers have earned this money by sacrificing their bodies to save a life. Creditors should not be able to collect money that was earned from organ sales because the purpose of the market is to encourage consensual life saving transactions.

6.) The market should be limited to Americans. On the basis of practicality, accessing medical records of Americans is easier than accessing the medical records of foreign citizens. ${ }^{375}$ The organ provider's medical history is highly germane to the transplant procedure. Ensuring the organ provider receives adequate post-operative care and healthcare subsequently requires the organ seller to be an American domiciliary. ${ }^{376}$ Restricting the market to Americans decreases the likelihood of exploitation of citizens

373 Fabian, supra note 87.

374 Hippen, supra note 304, at 10.

375 BEARD ET AL., supra note 71, et al. at 204.

376 Id. 
from impoverished foreign nations though the screening process should detect and remove such people from the market.

\section{B. Cadaver Organ Market}

Becoming a cadaver organ seller can occur through the same channels one currently becomes an organ donor postmortem. The complicating factor is having the future organ seller allocate the payment after his death; however, this obstacle is easily overcome. The best solution would be having the seller allocate the money in a testament. In the absence of a written will, the money could be distributed via the laws of intestacy. A voucher for funeral expenses may also be an effective way of compensating organ providers, as demonstrated by Spain. ${ }^{377}$

Establishing a price for cadaver organs is complicated for the same reason as establishing a price for live organs: there are not many legal examples. One scholar suggested setting a cadaver price for each major organ at $\$ 864.27$ in 2008,378 roughly $\$ 938$, adjusting for inflation. ${ }^{379}$ Although the sale of cadavers is illegal, firms charge to process and store cadavers. ${ }^{380}$ Corpses can be procured for $\$ 10,000$ and generate up to $\$ 200,000$ from the tissues. ${ }^{381}$ Therefore, a lump sum payment of $\$ 1,000$ is a reasonable base rate for

377 See discussion of the Spanish system supra.

378 Lloyd R. Cohen, Directions for the Disposition of My (and Your) Vital Organs, REGULATION 33 (Fall 2005), http://object.cato.org/ sites/cato.org/files/serials/files/regulation/2005/9/v28n3-1.pdf [http:// perma.cc/XXB2-TPYA].

379 CPI Inflation Calculator, Bureau of Labor Statistics, http://www.bls.gov/data/inflation_calculator.htm [http://perma.cc/W65PQULE] (last visited Apr. 8, 2015).

380 Kate Wilson et al., Skin, Bones and Tissue for Sale: How the Dead Are Being Used for Grisly Trade in Human Body Parts (July 18, 2012), http://www.dailymail.co.uk/news/article-2175006/Skin-bones-tissue-saleHow-dead-used-grisly-trade-human-body-parts [http://perma.cc/7LD4$\mathrm{L} 5 \mathrm{QH}]$.

381 Id. 
each cadaver organ. The sum could be even higher as only about one percent of cadaver organs are transplantable. However, there may be bars on payment in some cases. The law should not create an incentive for people to pull the plug on their parents nor commit suicide as a means of bettering their family financially. Keeping a brain-dead person alive already costs families, so money is already an issue in the equation. Suicide is the more challenging issue, particularly in right to die states.

\section{VIII.CONSEQUENCES OF ORGAN MARKET}

The intended and presumable consequence of an organ market is an increase in the number and quality of organs available. ${ }^{382}$ The poor will likely have better access to organs, as evinced by the Iranian example; thus, a legal organ market will provide more equitable health outcomes than the current system. ${ }^{383}$ More organs means less time waiting for the needed organ, ${ }^{384}$ and less time waiting for organs results in better health outcomes for the organ recipient. ${ }^{385}$ Plus, the increased supply of organs should result in better matches for the recipient's body. ${ }^{386}$ A greater supply of organs means more transplants can be performed, so more lives will be saved.

Regarding kidney transplants, the procedure is highly preferable for most patients with end stage renal disease from both economic and health perspectives. ${ }^{387}$ Gary Becker

382 Andrew V. Scott \& Walter E. Block, Organ Transplant: Using the Free Market Solves the Problem, 2 J. CLINIC. RES. BIoETHICS 1, 2 (2011), available at http://omicsonline.org/organ-transplant-using-the-freemarket-solves-the-problem-2155-9627.1000111.pdf [http://perma.cc/ GW2X-2276].

383 Capaldi, supra note 158, at 12.

384 Cash for Kidneys, supra note 92.

385 Introducing Incentives, supra note 121, at 14-15

386 Aziz, supra note 5, at 81.

387 Alan Langnas \& Daniel R. Salomon, Op-Ed, Remove Disincentives to Organ Donation, THE N.Y. TIMES (Aug. 21, 2014), http:// 
and Julio Elias write, "Most of those on dialysis cannot work, and the annual cost of dialysis averages about $\$ 80,000$. The total cost over the average 4.5-year waiting period before receiving a kidney transplant is $\$ 350,000$, which is much larger than the $\$ 150,000$ cost of the transplant itself." 388 The price of immunosuppressant drugs is much cheaper than dialysis, ${ }^{389}$ so even factoring drug expenditures, savings are accrued. Lower doses of immunosuppressant drugs will be required with better organ matches resulting in further savings. ${ }^{390}$ Providing dialysis patients with timely transplants could save the federal government $\$ 200,000$ per year per patient. 391 The total cost of kidney transplants may decrease as well because the market should reduce kidney procurement costs. ${ }^{392}$ Additionally, the stress on patient families will be ameliorated. Similar patient outcomes are expected for those in need of organs other than kidneys because a market for cadaver organs will increase the supply of all organs.

Aside from saving American lives, legalizing the organ market will damper the horrid happenings of the black market. Legalization is the most effective way to destroy underground markets. There is nothing inherently evil involved in giving up a kidney for money. The malevolence associated with black market organ sales germinates in the darkness of the underworld. Providing a legal framework

www.nytimes.com/roomfordebate/2014/08/21/how-much-for-a-kidney/ remove-disincentives-to-organ-donation [http://perma.cc/7ZAA-XZLK].

388 Cash for Kidneys, supra note 92.

389 Mycophenolate Mofetil Prices, Coupons and Patient Assistance Programs, DRUGS.com (Oct. 23, 2015) http://www.drugs.com/priceguide/mycophenolate-mofetil [http://perma.cc/5298-MEGR] (showing that mycopheonlate mofetil tablets cost $\$ 122.44$ for 100 capsules at $500 \mathrm{mg}$ ).

390 Brochure, From Me To You-So Your Relative Needs a Kidney, RENAL RESOURCE CENTRE, (Apr. 8, 2015), http://www.renalresource.com/ brochures/syrnak.php [http://perma.cc/9DV5-E53J].

391 FRY-REVERE, supra note 153, at 206.

392 Cash for Kidneys, supra note 92; Introducing Incentives, supra note 121 , at 12 . 
offers protection to buyers and sellers. Both parties are fully informed of the risks of the operation, and both parties can use the law in their favor. Sellers will be ensured they receive their wage. If they do not, the courts offer a legitimate mechanism for righting wrongs occurring during the process. Organ recipients have no need to worry about the quality of their surgeon or the organ's quality as proper medical protocol governs the transplant in legal operations. Those on transplant waiting lists will have less incentive to explore illegal organ procurement options because more legal organs will be available. Likewise, desperate and incompetent people are shielded from exploitation in a legal market.

A potential ancillary benefit of legalizing the organ market is improved public health. ${ }^{393}$ Most transplants arise from preventable, obesity related conditions such as type 2 diabetes and hypertension. If only non-obese individuals are allowed to sell their organs, people have an additional reason to control their weight. Even people who have no intentions of selling a kidney while alive may be interested in selling their organs postmortem. This incentive does not intrude into peoples' lives and is in no way paternalistic. It simply provides a potential reward for a healthy lifestyle. An improved level of public health would reduce the number of transplants needed.

\section{IX.CONCLUSION}

The American and international organ procurement laws are not designed to increase organ supply; instead, the legal framework hopes to prevent commodification of the body. ${ }^{394}$ This may be a worthy goal, but it does not save lives. Thousands of people waste away on dialysis each year due to the kidney shortage. An unknown number of others forego the wait and take their chances on the black market. Unfortunately, this desperate attempt to save their own lives often results in the exploitation of the indigent.

393 Scott \& Block, supra note 382, at 2.

394 Mayes, supra note 13, at 2. 
There are two hopes for alleviating the organ shortage. Technology holds tremendous promise, but thousands of lives will be lost before technology offers a remedy to the organ shortage. These deaths are unnecessary because there are viable organs available for transplant. However, the owners of these organs lack incentives to part with their organs. Altruism, the engine of the current organ procurement model, simply is not enough. ${ }^{395}$ Therefore, a market based approach should be applied to the organ shortage.

Though some oppose markets, legalizing the organ trade best addresses market opponents concerns. A legal framework protects sellers from the wretched, exploitive practices that are commonplace on the black market. Recipients and sellers both receive better care when the procedure is legal because the law offers them quality assurances. Furthermore, equitable access to transplants is better ensured under a legal organ market. The same exact organ distribution procedures that are in place at present can continue even if monetary incentives are involved.

Some may fear creating a market for organs allows humans to buy more life; that is, those with means can keep purchasing replacement parts indefinitely. This concern is irrelevant to an organ market for a few reasons. First of all, a market for organs would simply make a widely accepted medical procedure-organ transplantation-more efficient. Legalizing the organ trade does not open any new doors from a medical technology perspective. Building off the first objection, the second objection is that it is theoretically possible for an individual to procure an unlimited supply of new body parts already. An individual can legally persuade people to donate their organs; thus, a patient in need of an organ with the oratory ability of Clarence Darrow may be able to convince multiple people to part with their organs. Additionally, a person in need of a transplant with a large squadron of exceptionally generous friends can engage paired donations endlessly essentially enabling a person to obtain an infinite number of organ transplants via barter. A more 
likely scenario would be a supremely wealthy individual who keeps purchasing organ transplants on the black market.

There are valid concerns about how far science should go in its efforts to save a life. At what point do efforts to preserve life begin to create a Frankenstein? For example, should 3D printed organs be better than "natural" human organs? Failure of the heart's left main artery causes heart attacks, so researchers are already trying to design hearts with two left main arteries making death by heart attack much less likely. ${ }^{396}$ Genetic engineering presents similar issues and arguably raises more complex ethical challenges. Doctors have tried transplanting animal organs into humans, known as xenotransplantation, for over 50 years. 397 Xenotransplants originally achieved very limited success. ${ }^{398}$ However, genetic engineering has the potential to transform pig organs into a viable medical option for humans in need of organs. ${ }^{399}$ These issues are certainly worthy of discussion, but they have little relevance to a market for organs. A market is not a biomedical breakthrough. On the contrary, a market may be the most basic mechanism for allocating resources.

Only one country has eliminated its kidney shortage. Unsurprisingly, this is the only country with a market style incentive for kidney providers. Basic economics and experience demonstrate a market for organs can end the organ shortage. Legalizing the trade in organs also happens to be the most ethical option at this time. It reduces suffering and death, respects individual autonomy, distributes organs in a socially desirable fashion, saves money, and helps end the maleficent underground organ trade.

396 John Graber, Report Predicts Possible Ban on Bioprinting by 2016, 3D PRINTER WORLD (Feb. 14, 2014), www.3dprinterworld.com/ article/report-predicts-possible-ban-bioprinting-2016 [http://perma.cc/ ZE85-ZAS7].

397 Shima Benham Manesh et al., Ethical Issues of Transplanting Organs from Transgenic Animals into Human Beings, 16 CELL J. 353, 354 (Aut. 2014), available at www.ncbi.nlm.nih.gov/pmc/articles/ PMC4204195/pdf/Cell-J-16-353.pdf. [http://perma.cc/2LCK-REDF].

398 Id.

399 Id. 